\title{
ARTIKEL
}

\section{De organisatie van het ziekenhuis: integratieproces of Echternach-processie?}

\author{
Prof. mr. L.G.H.J. Houwen*
}

\section{Inleiding}

Exact een halve eeuw geleden maakte de toenmalige Nijmeegse hoogleraar W.C.L. van der Grinten tijdens een van de eerste gezondheidsrechtelijke congressen 'tussen Themis en Aesculaap' zijn toehoorders deelgenoot van zijn observaties omtrent het Nederlandse ziekenhuiswezen: 'Het ziekenhuis bevindt zich in een ontwikkelingsfase, die waarschijnlijk nog niet is voltooid. (...) De moderne ontwikkeling is, dat het ziekenhuis in steeds toenemende mate tot een gesloten instelling wordt. (...) De medische verrichtingen van de specialisten worden meer en meer met het medisch hotel verbonden. Als ik het wel zie, is het integratieproces thans in volle gang. (...) men kan zich afvragen of de moderne ontwikkeling niet tendeert naar een andere verhouding tussen arts en ziekenhuis. ${ }^{1}$ Het 'handelen van de geneesheer en diens plaats in de structuur van de gezondheidszorg' ${ }^{2}$ beheerst sindsdien met enige regelmaat de politieke en fiscale alsook de juridische agenda. De invoering van de integrale bekostiging en de daarmee gepaard gaande oprichting van medisch specialistisch bedrijven vormen het meest recente hoogte- of dieptepunt, al naar gelang het perspectief van de deelnemer aan dit bij tijd en wijle hoogoplopend debat. In deze bijdrage ga $\mathrm{ik}$ nader in op deze ontwikkelingen en met name de vraag of er in die halve eeuw op het gebied van wat wij nu in moderne termen 'governance' noemen maar gewoon gaat over de organisatie, bestuur en verantwoording van het ziekenhuis, ook daadwerkelijk vooruitgang is geboekt: is er sprake van een gestaag (evolutionair) integratieproces of kan de zoektocht naar een functionele governance van de ziekenhuisorganisatie beter als een 'Echternach-processie' worden geduid, waarbij de medische professie en het bestuurlijke echelon wel hand in hand als een soort twee-eenheid optrekken, maar via onregelmatige hinkstapsprongen na drie stappen vooruit toch steeds weer twee stappen achteruit zetten? Na een

* Louis Houwen is bijzonder hoogleraar privaat-publiek ondernemingsrecht Tilburg University, Tias, School for Business and Society en advocaat bij Dirkzwager advocaten \& notarissen te Nijmegen.

1 W.C.L. van der Grinten, 'Het ziekenhuis en zijn juridische relaties met geneesheer en patiënt', in: De geneesheer en het recht, Serie Medisch Recht, nr. 1, Deventer: Kluwer 1968, p. 43-52, waarin hij pleit voor een loondienstverband: 'De ontwikkeling van het ziekenhuis tot medisch centrum en de daarmee gepaard gaande incorporatie van de aan het ziekenhuis verbonden artsen in de ziekenhuisorganisatie wijzen in de richting van een arbeidsovereenkomst.', hetgeen overigens geen afbreuk hoeft te doen aan de professionele autonomie: 'met de juridische ondergeschiktheid van de arbeidsovereenkomst is niet in strijd onafhankelijkheid van beslissing omtrent medische verrichtingen' of aan de waardigheid van het artsenberoep: 'ook de hoogleraar is juridisch ambtenaar of arbeider'.

2 A.A.M. van Agt en J.M.M. Maeijer, 'Ten geleide', in: Juridische problemen in en rond het ziekenhuis, Serie Medisch Recht, nr. 4, Deventer: Kluwer 1971, p. 7. 
korte schets van de historische ontwikkeling van het ziekenhuisbedrijf in de laatste decennia, richt de focus van dit artikel zich op de organisatorische en bestuurlijke inrichting van het medisch specialistisch bedrijf (MSB) binnen de context van de moderne ziekenhuisorganisatie. Op basis van de onderzoeksrapporten van Tias en de NZa worden zowel de positieve effecten van de MSB-vorming als de risico's van deze ontwikkelingen geadresseerd en met name de governancedilemma's ten aanzien van de besturing en het interne toezicht van ziekenhuizen geanalyseerd. Deze bevindingen vormen vervolgens evenzoveel uitdagingen voor een schets van het toekomstperspectief van een mogelijke doorontwikkeling van het MSB naar een volwaardige ziekenhuisorganisatie. De aansporing van Marcel Levi in zijn recente Domus Medica lezing, 'Professionals, neem zelf de leiding over de zorg', staat daarbij centraal. ${ }^{3}$ Een oproep die langzaam weerklank schijnt te vinden, maar waarvan de implicaties in bestuurlijk opzicht en de daaruit voortvloeiende verantwoordelijkheden voor de inrichting van de toekomstige ziekenhuisorganisatie nog niet in alle opzichten zijn doordacht.

\section{Ontwikkelingen (governance) curatieve zorg}

Door alle veranderingen in de geneeskunde, de medische technologie, de organisatie en bekostiging van de zorgsector, de betrokkenheid van patiënten en andere interne en externe belanghebbenden en ten slotte de governance, staan de traditionele ziekenhuisstructuren, zowel intern als extern, de laatste jaren onder druk. Naar de buitenwereld toe staat de onderlinge samenwerking respectievelijk substitutie tussen de eerste-, tweede- en derdelijnszorg door nieuw overheidsbeleid en de verschillende hoofdlijnakkoorden van de afgelopen jaren inmiddels scherp op het netvlies van veel ziekenhuizen. Veelal tezamen met het besef van een onvermijdelijke herpositionering van ziekenhuisfuncties door specialisatie en concentratie van hoogcomplexe en intensieve acute zorg in regionale (academische en topklinische) ziekenhuizen met daarnaast meer lokale (kleinschalige, generalistische of gespecialiseerde) centra voor poliklinische en dagbehandeling van laagcomplexe acute en electieve basiszorg (zoals orthopedie, oogheelkunde of dermatologie) in meer fluide netwerkorganisaties. ${ }^{4}$ In de interne organisatie wordt de traditionele afdelingsstructuur al (voorzichtig) vervangen door multidisciplinaire zorg- en patiëntpaden rondom specifieke aandoeningen omdat de oude structuur te veel versnippering en te weinig samenwerking oplevert.

\section{Duale organisatiestructuur}

Op het gebied van governance van algemene en categorale ziekenhuizen is met name de duale organisatiestructuur eigenlijk al lang over haar houdbaarheidsdatum heen. Het primaire proces, de medisch-specialistische behandeling van patiënten, wordt van oudsher grotendeels verricht door betrekkelijk autonome medisch specialisten in vrije vestiging

3 M. Levi, 'Professionals, neem zelf de leiding over de zorg', Medisch Contact 2018/01-02, p. 30-33.

4 Recent over deze ontwikkelingen: Rapport Taskforce, De juiste zorg op de juiste plek. Wie durft?, april 2018, p. 39 e.v. en p. 73; NZa, Stand van de zorgmarkten 2017; en NVZ, Brancherapport algemene ziekenhuizen 2017; Kamerstukken II 2017/18, 29248 (Invoering Diagnose Behandeling Combinaties), 308, brief van de minister voor Medische Zorg d.d. 6 december 2017, p. 4. 
met een praktijkvoering voor eigen rekening en risico. Voor deze zelfstandige beroepsuitoefening draagt de individuele medisch specialist persoonlijk professionele verantwoordelijkheid en kan daar ook tucht- en civielrechtelijk op worden aangesproken. De verzorging, verpleging en overige dienstverlening aan patiënten alsmede de facilitaire ondersteuning en ruimtelijke voorzieningen worden door het ziekenhuis verzorgd en gefinancierd. De financiële deelregulering van ziekenhuisbudget en specialistenhonorarium is in 2015 afgeschaft, waardoor het duale bekostigingsmodel weliswaar tot het verleden behoort, maar de duale organisatiestructuur is in de loop der jaren echter behoorlijk vastgeroest in veel ziekenhuizen. De kern van de daaruit voortvloeiende governanceproblematiek is tweeledig en ziet op (i) een geïnstitutionaliseerd belangenconflict en (ii) een onevenwichtige verantwoordelijkheidsverdeling binnen de ziekenhuisorganisatie. De medisch-specialistische zorgverlening vindt ook in het huidige tijdsgewricht nog steeds in belangrijke mate plaats door en voor eigen rekening van (het collectief van) medisch specialisten terwijl de formele 'eindverantwoordelijkheid' door de Wet kwaliteit, klachten en geschillen zorg (Wkkgz) exclusief wordt toebedeeld aan de zorgaanbieder, dat wil hier zeggen de rechtspersoon die (niet binnen het kader van de binnen een andere instelling verleende zorg) bedrijfsmatig zorg verleent.

\section{Geintegreerd Medisch Specialistisch Bedrijf}

Deze problematiek kent een lange voorgeschiedenis: zo constateerde de toenmalige Statuskommissie van Het Nederlandse Ziekenhuiswezen en de Vereniging van Katholieke Ziekenhuizen al in 1965 enige 'spanning tussen de koördinatie die in het ziekenhuis - zo goed als in elke andere organisatie - noodzakelijk is, enerzijds, en de zelfstandigheid waarop de behandelend geneesheer aanspraak kan maken, anderzijds'. ${ }^{5}$ Rond de eeuwwisseling is gezocht naar een oplossing voor dit spanningsveld door de introductie van het Geïntegreerd Medisch Specialistisch Bedrijf (GMSB). Dit organisatiemodel gaat uit van nevenschikking op decentraal en operationeel niveau door managementparticipatie van medisch specialisten en onderschikking in de topstructuur door de wettelijke 'eindverantwoordelijkheid' voor de integrale zorgverlening neer te leggen bij de raad van bestuur van het ziekenhuis. Tevens werd het eigen declaratierecht en de zelfstandige onderhandelingspositie van de medisch specialisten jegens zorgverzekeraars afgeschaft en bij het ziekenhuis gesitueerd. Met de verschillende vormen van duaal management heeft deze wettelijke maatregel op decentraal niveau waarschijnlijk nog wel een positief effect gesorteerd, maar financieel en in de besturing van het ziekenhuis is uiteindelijk weinig veranderd. Met een gekunstelde 'via-constructie' werd het honorariumdeel van het totale DBC-tarief - virtueel - nog steeds separaat gedeclareerd, waardoor via een evenzeer creatieve redenering het, al dan niet virtueel, fiscaal ondernemerschap overeind werd gehouden. Om financieel-economisch en organisatorisch tegenwicht te bieden aan de door de Integratiewet beoogde machtspositie van de raad van bestuur in de topstructuur werden daarentegen wel massaal collectieven van vrijgevestigde medisch specialisten opgericht (voornamelijk maatschappen en coöperaties) die als belangenbehartiger en onderhandelingspartner van de raad van bestuur fungeerden. Door deze formalisering van hun collectieve machtspositie werd de

5 Statuskommissie van de Stichting Het Nederlandse Ziekenhuiswezen en de Vereniging van Katholieke Ziekenhuizen en Het Gemeenschappelijk Instituut voor Toegepaste Psychologie, De organisatorische positie van de medisch specialist in het Nederlandse algemene ziekenhuis, Nijmegen-Tilburg: augustus 1965, p. 4. 
integratie van de medisch specialisten in de ziekenhuisgemeenschap niet direct bevorderd, maar het (latente) belangenconflict veeleer geïnstitutionaliseerd in de organisatiestructuur van het ziekenhuis. ${ }^{6}$

\section{Tijdelijk Beheersmodel Honorariumomzet}

Het Tijdelijk Beheersmodel voor de honorariumomzet van vrijgevestigde medisch specialisten dat voor de transitieperiode van de overgang naar volledige integrale bekostiging in 2011 is overeengekomen met de betrokken branche- en beroepsorganisaties, ${ }^{7}$ continueert deze hybride situatie in wezen. De oprichting of het 'revitaliseren' van de stafmaatschap en de coöperatie als rechtsvormen van het collectief van de vrijgevestigde medisch specialisten om gezamenlijk afspraken te maken met de raad van bestuur over de interne verdeling van het honorariumbudget, zoals toentertijd geadviseerd door de Orde van Medisch Specialisten (OMS), ${ }^{8}$ heeft de geïnstitutionaliseerde belangenbehartiging in de onderhandelingsarena van het ziekenhuis eigenlijk alleen maar bestendigd. Welbeschouwd hebben deze juridische overgangsvormen als kwartiermaker avant la lettre voor het huidige samenwerkingsmodel met een zelfstandig MSB binnen de ziekenhuismuren gefungeerd.

\section{Medisch Specialistisch Bedrijf}

Het samenwerkingsmodel zoals zich dat sinds 2015 in het kader van de integrale bekostiging bij de meeste Nederlandse ziekenhuizen onder de noemer van het MSB manifesteert in uiteenlopende verschijningsvormen, is naar mijn overtuiging dan ook geen tijdelijk fenomeen. Het vormt als uiting van een hardnekkig governancevraagstuk de resultante van een consistent verzelfstandigingsproces van medisch specialisten dat het duale bestuursmodel van het ziekenhuis omstandig formaliseert, het (potentiële) belangenconflict tussen medisch specialisten en (de raad van bestuur van) het ziekenhuis verder institutionaliseert, en ten slotte de (vacante) verantwoordelijkheid van medisch specialisten voor de kwaliteit van de integrale zorgverlening en de totale (financiële) bedrijfsvoering van het ziekenhuis onvoldoende adresseert. Deze bevindingen en de gevolgen daarvan voor de governance zal ik in het vervolg van dit artikel nader toelichten.

\section{Perspectieven en risico’s MSB}

De invoering van het systeem van integrale bekostiging voor medisch-specialistische zorg met de aankondiging van het verlies van het fiscaal ondernemerschap en de dreigende impact van de Wet normering topinkomens (WNT) hebben tegen het einde van de transitieperiode geresulteerd in de (formele) oprichting per 1 januari 2015 van grootschalige MSB-structuren bij de meeste Nederlandse ziekenhuizen. Volgens een vast fiscaal stramien

6 L.G.H.J. Houwen, Van maatschappelijk belang, maatschappelijk belang als normatief governancemodel, oratie Tilburg, 2011, p. 70-73; met verwijzing naar onder andere G.R.M. Scholten \& T.E.D. van der Grinten, 'De integratie van medisch specialisten in Nederlandse ziekenhuizen, een organisatiekundige beschouwing', Acta Hospitalia 2000-3, p. 31-43.

7 Convenant Bekostiging vrij gevestigd medisch specialisten transitie 2012-2014; Kamerstukken II 2010/11, 29248, 165, 170 en 211.

8 Orde van Medisch Specialisten, Het Witte Boek deel IV, Beheersmodel medisch specialisten en vorming van een collectief, Utrecht: juni 2011. 
hebben de meeste vrijgevestigde medisch specialisten daartoe hun praktijk en maatschapsaandeel persoonlijk ingebracht in een eigen praktijkvennootschap met de betrokken specialist als directeur-aandeelhouder. Via individuele aansluitings- of ledencontracten verkrijgen deze praktijkvennootschappen vervolgens het lidmaatschap van doorgaans een coöperatie, of soms een bv, die het medisch specialistisch bedrijf exploiteert. Als alternatief voor deze corporatieve rechtsvormen heeft een aantal collectieven met voldoende 'ondernemingssubstance' om aan het fiscaal zwaardere risicoprofiel te voldoen, gezamenlijk een fiscaal transparante maatschap gevormd. ${ }^{9}$ Het MSB vormt als zodanig een juridisch, financieel-economisch en vooral fiscaal zelfstandig bedrijf van medisch specialisten dat voor eigen rekening en risico via een collectieve samenwerkingsovereenkomst de medisch-specialistische zorg contracteert met het ziekenhuis en in dat kader ook zelfstandig geneeskundige behandelingsovereenkomsten met de patiënten kan sluiten. De verdere uitwerking van dit samenwerkingsmodel, met name de wijze waarop het MSB intern is georganiseerd en zorginhoudelijk, financieel en bestuurlijk de relatie met het ziekenhuis heeft ingericht, wordt doorgaans sterk fiscaal bepaald en vertoont lokaal de nodige verschillen. Voor de deelnemende medisch specialisten wordt daarmee de status van vrije beroepsbeoefenaar in de nieuwe bekostigingssystematiek (vooralsnog) gecontinueerd en, naar eigen zeggen, hun professionele autonomie beter gewaarborgd.

\section{Onderzoek Tias en NZa}

Volgens de toenmalige minister van VWS kent het MSB van de drie voorhanden organisatiemodellen de grootste risico's, met name voor de bestuurbaarheid van het ziekenhuis. Naast het loondienstverband ziet zij het participatiemodel met medisch specialisten als mede-eigenaar, als 'lonkend perspectief' omdat het naar verwachting 'de gelijkgerichtheid faciliteert'. ${ }^{10}$ Vanwege deze zorgen over de gevolgen van de MSB-vorming voor de governance van ziekenhuizen heeft de minister onderzoek laten doen naar de effecten van dit samenwerkingsmodel in de praktijk en een tweede monitor integrale bekostiging van de $\mathrm{NZa}$ aangekondigd waarin ook de verschillende verschijningsvormen van het MSB worden betrokken. Dat heeft geresulteerd in een tweetal onderzoeksrapportages: Op weg naar gezamenlijkheid. Rapportage Quick Scan Integrale bekostiging en governance van Tias, School for Business and Society; en de Monitor integrale bekostiging medisch specialistische zorg van de NZa. ${ }^{11}$ Het Tias-onderzoek geeft specifiek inzicht in de wijze waarop de raad van bestuur en de raad van toezicht hun bestuurlijke respectievelijk toezichthoudende verantwoordelijkheid voor de kwaliteit en veiligheid van de medische zorgverlening en een correcte registratie en declaratie borgen. De NZa presenteert in haar jaarlijkse monitor kwantitatieve cijfermatige bevindingen en een algemene kwalitatieve analyse op basis van voornamelijk enquête- en interviewresultaten. Beide rapporten geven een genuanceerd en gedifferenti-

9 Uitvoerig over de fiscale implicaties van de integrale bekostiging en MSB-vorming: P.H.J. Essers, M. Moors en S.A. Stevens, 'Fiscale positie medisch specialisten in de huidige en toekomstige financierings- en bekostigingssystematiek', in: Financiering van zorginstellingen, Met speciale aandacht voor medisch-specialistische zorg, Deventer: Vakmedianet 2015, p. 333-354.

10 Kamerstukken II 2014/15, 29248, 285, brief van de minister van Volksgezondheid, Welzijn en Sport d.d. 30 juni 2015, p. 3.

11 Tias, School for Business and Society, Op weg naar gezamenlijkheid - Rapportage Quick scan integrale bekostiging en governance, Tilburg: 14 januari 2016; en NZa Monitor integrale bekostiging medisch specialistische zorg 2015, Utrecht: 23 februari 2016. 
eerd beeld van de effecten van MSB-vorming in Nederlandse ziekenhuizen waarbij zowel risico's van zelfstandige MSB-structuren worden geïdentificeerd als positieve effecten van de MSB-vorming naar voren komen. Bevindingen die nadien op onderdelen door specifiek onderzoek en analyse van praktijkcasus worden bevestigd.

\section{Verworvenheden en perspectieven}

De overgang van de conventionele, decentrale maatschapsstructuur van het vrijgevestigde smaldeel van de medische staf, in het verleden regelmatig afgeschilderd als 'een eilandenrijk gebouwd rondom specifieke deskundigheden', ${ }^{12}$ naar een meer collectief georganiseerd samenwerkingsmodel met een of meerdere MSB's in het ziekenhuis heeft in ieder geval volgens de MSB-enquêterespondenten van de NZa het alignement tussen de vrijgevestigde medisch specialisten onderling vergroot: 'er is minder onderlinge strijd tussen medisch specialismen en een grotere eenheid tussen vrijgevestigde medisch specialisten' en zij (...) 'spreken meer met één stem en werken beter samen dan voorheen'. ${ }^{13}$ Daardoor is er meer ruimte voor multidisciplinair overleg en wordt de samenwerking tussen de verschillende specialismen bevorderd. Bij veel MSB's is bovendien enigerlei vorm van inkomensharmonisatie geïntroduceerd, veelal in combinatie met de vervanging van oude goodwillregelingen door meer actuele inverdien- en uitstroomvoorzieningen waardoor de toe- en uittreding voortaan niet meer in maatschapsverband maar op collectief niveau plaatsvindt. Het MSB heeft hiervoor meer financiële ruimte en slagkracht, hetgeen ook ruimere mogelijkheden biedt voor substitutie van (sub)specialisaties waardoor men bewuster en flexibeler kan inspelen op interne portfoliokeuzes en externe factoren als selectieve zorginkoop door zorgverzekeraars of concurrerende activiteiten van zelfstandige behandelcentra, privéklinieken of naburige ziekenhuizen. ${ }^{14}$ Dat sluit aan bij de grotere betrokkenheid van het MSB bij de (professionele) werving en selectie van nieuwe specialisten alsmede het intern zuiverend vermogen door het aanspreken van disfunctionerende specialisten of het ingrijpen bij geconstateerde incompatibiliteiten. Hetgeen overigens wel een daadwerkelijke bereidheid met voldoende mandaat en vooral bestuurlijke competenties van het MSBbestuur veronderstelt om snel en doortastend op te treden in een relatie met gelijkwaardigen. ${ }^{15}$ Een belangrijke en breed gedragen verworvenheid van dit samenwerkingsmodel vormt voorts het MSB-bestuur als centraal aanspreekpunt (overleg- en onderhandelingspartner) voor de raad van bestuur in plaats van de afzonderlijke maatschappen. In een open bestuurscultuur van wederzijds vertrouwen en informeel overleg kan dat de bestuurbaarheid van het ziekenhuis bevorderen. ${ }^{16}$ Via dit bestuur van het MSB kan ten slotte de betrokkenheid van de medisch specialisten bij het ziekenhuisbeleid (strategie, bedrijfsvoering en kwaliteitsbeleid) worden versterkt en verdere professionalisering van medisch specialisten, zowel financieel, bestuurlijk en strategisch worden bewerkstelligd.

R. Steenbergen, Vacante verantwoordelijkheid in het ziekenhuis, Zeist: 2005, p. 101-105; Scholten \& Van der Grinten (zie noot 6), p. 39.

13 NZa Monitor integrale bekostiging, p. 20 en 40.

14 Vgl. ook D.H. Biesma, 'De rol van de medisch specialist', in: Artsen met verstand van zaken, Utrecht: De Tijdstroom 2016, p. 107.

15 Tias-rapportage Integrale bekostiging en governance, p. 3 en 25; Biesma, 'De rol van de medisch specialist', p. 108.

16 NZa Monitor integrale bekostiging, p. 40; Tias-rapportage Integrale bekostiging en governance, p. 40. 


\section{Risico's en knelpunten}

In beide onderzoeksrapporten worden ook risico's van zelfstandige MSB-structuren geadresseerd. De meeste samenwerkingsverbanden gaan, in lijn met de landelijke (fiscale) modellen, conceptueel uit van een 'business-to-businessmodel' met twee of soms meer autonome bedrijven die ieder voor zich een eigen onderneming met eigen (financiële) deelbelangen exploiteren en hun deel van de medisch-specialistische zorg ten behoeve van de patiënten van het ziekenhuis verlenen. Overwegingen ontleend aan de fiscaliteit, professionele autonomie en een (latente) vrees voor inkomensnormering (WNT) schragen deze voortschrijdende formalisering en verzelfstandiging. Van een gemeenschappelijke ziekenhuisonderneming is in dit model geen sprake: op grond van de samenwerkingsovereenkomst leveren partijen weliswaar gezamenlijk een zorgproduct, maar zij sluiten daartoe vaak afzonderlijk geneeskundige behandelingsovereenkomsten voor hun aandeel in de zorgverlening (namelijk: de medisch-specialistische verrichtingen door het MSB en de verpleging, verzorging en deels behandeling door ziekenhuis) en handelen daarbij voor eigen rekening en risico. MSB en ziekenhuis vormen zo in de basis geen belangengemeenschap met integrale zorgverlening onder collectieve verantwoordelijkheid en voor gemeenschappelijke rekening en risico. Daarmee kent een dergelijk samenwerkingsmodel als zodanig geen intrinsieke gelijkgerichtheid van belangen, maar dient dat alignement - zorginhoudelijk, financieel-economisch en organisatorisch - contractueel te worden geregeld en zullen de betrokken partijen tegengestelde belangen bestuurlijk en operationeel zorgvuldig op elkaar af moeten stemmen. In financieel opzicht worden doorgaans afspraken gemaakt op grond waarvan het MSB een percentage van de ziekenhuisomzet ontvangt ofwel in een klant-leverancier verhouding vaste productie- en prijsafspraken maakt. ${ }^{17}$ Voorts worden regelmatig gezamenlijke doelstellingen en verantwoordelijkheden geformuleerd in de samenwerkingsovereenkomst, een en ander evenwel uitdrukkelijk onder verwijzing naar de 'juridische eindverantwoordelijkheid' van de raad van bestuur voor de kwaliteit, veiligheid en omvang van de zorgverlening. Dergelijke contractuele voorzieningen nemen niet weg, dat de onderliggende zakelijke verhoudingen in een onderhandelingsarena kunnen resulteren en een risico kunnen vormen voor de slagvaardige en effectieve bestuurbaarheid van het ziekenhuis door de raad van bestuur en het toezicht daarop door de raad van toezicht. Dat zal natuurlijk ook afhankelijk zijn van de persoonlijke relatie, het onderlinge vertrouwen en de professionele cultuur binnen het ziekenhuis, ${ }^{18}$ maar zo'n onderhandelingsmodel impliceert niettemin een latent spanningsveld waarbij toekomstige factoren

17 Tias-rapportage Integrale bekostiging en governance, p. 40; en nadien bevestigd door onder andere de Onderzoeksrapportage van EY: 'Onderzoek mogelijkheden tot bevorderen participatiemodel' d.d. 14 april 2017, p. 24.

18 Een verontrustende constatering, aldus K.D. Meersma ('Rutte III en het medisch specialistisch bedrijf I', ZIP 2017/165, p. 16): 'Effectief kwaliteitsbeheer als een resultante van onderlinge verhoudingen is uiterst onbevredigend, wellicht zelfs licht alarmerend.'; zie over het belang van deze factoren voor de samenwerking tussen het collectief van medisch specialisten en de raad van bestuur in het algemeen: R.M.A. van der Pennen, Besluitvorming in het ziekenhuis, dissertatie Tilburg University: 2016. 
zoals onvermijdelijke bezuinigingen van overheidswege, ${ }^{19}$ krimpstrategieën, zinnige maar vooral zuinige (meerjaren)contracten met zorgverzekeraars en interne portfoliokeuzes, de duurzaamheid van dit samenwerkingsmodel onder druk kunnen zetten. ${ }^{20}$

Deze risicofactor is inherent aan de (fiscale) systematiek van het samenwerkingsmodel. Daarnaast registreren beide onderzoeksrapportages mogelijke knelpunten bij de organisatie van het MSB binnen het ziekenhuisverband. Vanuit fiscale overwegingen wordt de doorzettingsmacht van ziekenhuisbestuurders jegens individuele medisch specialisten vaak sterk ingeperkt. Deze afnemende invloed van de raad van bestuur en de toenemende machtsfactor van het MSB 'om als collectief vorm te geven aan hun eigen professionele verantwoordelijkheid voor kwaliteit en veiligheid' wordt als een onevenwichtigheid in de uitwerking van het samenwerkingsmodel ervaren. Met name door ziekenhuisbestuurders omdat zij wettelijk, statutair en contractueel 'eindverantwoordelijk' worden gehouden voor de kwaliteit en veiligheid van de integrale zorgverlening, terwijl het primaat om dit te effectueren meer bij het MSB is komen te liggen en zij dan maar op het zelfreinigend vermogen van het MSB moeten vertrouwen. ${ }^{21}$ Deze onevenwichtigheid geldt in meer algemene zin voor de toepasselijkheid van veel relevante (gezondheidsrechtelijke) wet- en regelgeving, zoals de WTZi, WMCZ, Wkkgz, WNT en de Governancecode Zorg 2017. De (raad van bestuur van de) zorgorganisatie geldt daar als normadressaat, en niet het MSB als collectief van medisch specialisten dat het primaire zorgproces veelal controleert. Dat kan als een structurele weeffout in het MSB-model worden beschouwd. Medisch specialisten zijn weliswaar individueel - tuchtrechtelijk - verantwoordelijk voor hun eigen handelen maar dat laat onverlet, zoals zorgvuldig in de model-samenwerkingsovereenkomsten wordt 'gememoreerd', de 'eindverantwoordelijkheid' van de raad van bestuur voor de kwaliteit en veiligheid van de (integrale) zorgverlening en de governance van de ziekenhuisorganisatie. Dat geldt in wezen ook voor de civielrechtelijke aansprakelijkheid voor eventuele tekortkomingen in de uitvoering van de geneeskundige behandelingsovereenkomsten: contractueel kan de aansprakelijkheid en draagplicht natuurlijk bij het MSB worden neergelegd, maar op grond van de centrale aansprakelijkheid van het ziekenhuis (art. 7:462 BW) wordt dat al snel door het ziekenhuis 'geabsorbeerd'. Ten aanzien van de reikwijdte van de Wet normering topinkomens zit een vergelijkbare disbalans in de honorering van enerzijds de gemaximeerde ziekenhuisbestuurders en anderzijds de vrijgestelde medisch specialisten in het MSB-bestuur waar de WNT tot dusverre geen vat op heeft. Recent onderzoek bevestigt de constatering van het Tias-rapport dat de WNT een sterke rem op het toetreden van medisch specialisten tot de bestuurlijke gremia van het ziekenhuis lijkt te vormen: 'medici zijn minder gemotiveerd om een rol als bestuurder op zich te nemen omdat het inkomensverschil te groot is'. ${ }^{22}$ Deze onverklaarbare inkomensverschillen kun-

19 Het nieuwe Onderhandelaarsakkoord medisch-specialistische zorg 2019 t/m 2022 van 25 april 2018 (Kamerstukken II 2017/18, 29248, 309, bijlage) gaat uit van een hogere volumegroei voor (georganiseerde) huisartsenzorg, wijkverpleging en eerstelijnsverblijf met een lager groeipercentage voor het macrobudget medischspecialistische zorg van maximaal $0,8 \%$ in $2019,0,6 \%$ in $2020,0,3 \%$ in 2021 en $0,0 \%$ in 2022, exclusief indexatie voor loon- en prijsbijstelling.

20 In deze zin onder andere ook Biesma, 'De rol van de medisch specialist', p. 111.

21 Tias-rapportage Integrale bekostiging en governance, p. 37-38; en weliswaar ietwat minder kritisch: NZa Monitor integrale bekostiging, p. 21.

22 Boer \& Croon, Bestuurbaarheid van ziekenhuizen, Amsterdam: 15 maart 2017, p. 10-11. 
nen op termijn een bedreiging voor de gezamenlijke besturing van het ziekenhuis vormen. ${ }^{23}$

Het empirisch onderzoek van Tias maakt tevens inzichtelijk dat de meerderheid van de ziekenhuizen naast een groot MSB waarin een substantieel deel van de vrijgevestigde medisch specialisten zijn ondergebracht, nog één of meer afzonderlijke MSB's van separate vakgroepen, maatschappen of een klein tandheelkundig MSB kent. Volgens de NZa kan deze mogelijke versnippering van meerdere MSB's de bestuurbaarheid van het ziekenhuis bemoeilijken. Bovendien geldt voor vrijwel alle onderzochte ziekenhuizen dat per thema, specialisme of artsengroep nog altijd verschillende vertegenwoordigingen bestaan in de vorm van bijvoorbeeld organisatorische eenheden, afzonderlijke vakgroepen of de 'oude' maatschappen. De mate waarin binnen de medische staf ontschotting plaatsvindt en de collectiviteit wordt bevorderd, is dan niet alleen sterk afhankelijk van de financiële en feitelijke machtsverhoudingen, maar evenzeer van de vraag of de statutaire voorzieningen van de coöperatie of de maatschapsbepalingen voldoende mandaat en daarmee werkelijke doorzettingsmacht aan het MSB-bestuur toedelen dan wel het primaat in de interne checks and balances voornamelijk bij - autonome - vakgroepen leggen en op die manier nog steeds het - verouderde - consensusmodel cultiveren.

\section{Governancedilemma's ziekenhuisorganisatie}

De complexiteit van de interne bestuur- en toezichtstructuur als gevolg van de MSB-vorming is volgens de minister van VWS een serieuze risicofactor voor ziekenhuizen: 'de formele implementatie van het samenwerkingsmodel met een juridisch, fiscaal en financieel zelfstandig MSB (coöperatie of maatschap) naast de ziekenhuisstichting heeft in vrijwel alle ziekenhuizen geresulteerd in een meervoudige en complexe organisatie- en governancestructuur die onder kritieke omstandigheden een risico voor de bestuurbaarheid en het toezicht vormen'. ${ }^{24}$ Deze constatering raakt de kern van de governanceproblematiek van het samenwerkingsmodel die in wezen drieledig is, namelijk: (i) een overlegstructuur van ziekenhuisbestuur en medisch specialisten met meerdere geledingen (VMS, MSB en VMSD) en een diffuus beeld van onderlinge verantwoordelijkheden ten aanzien van kwaliteit en veiligheid, registratie en declaratie respectievelijk strategie en bedrijfsvoering; (ii) de meervoudige besturing van de ziekenhuisorganisatie met een onevenwichtige verantwoordelijkheidsverdeling tussen (raad van bestuur) ziekenhuis en medische professionals; en ten slotte (iii) de positie van de raad van toezicht die in het gedrang kan komen door de grotere afstand tot het primaire proces van de medisch-specialistische zorgverlening en het ontbreken van rechtstreekse interventiemechanismen.

23 Tias-rapportage Integrale bekostiging en governance, p. 36 en 41.

24 Kamerstukken II 2015/16, 32012 (Governance in de zorgsector), 39, brief van de minister van Volksgezondheid, Welzijn en Sport d.d. 4 juli 2016, p. 2, zulks in navolging van de Tias-rapportage Integrale bekostiging en governance, p. 4 en 39; vgl. ook meer recentelijk het besluit van de IGJ tot het instellen van verscherpt toezicht in een ziekenhuis d.d. 12 mei 2017 waar: '(...) de raad van bestuur door de medische staf onvoldoende in de gelegenheid werd gesteld haar verantwoordelijkheid te nemen voor kwaliteit en veiligheid van zorg en het intern toezicht blijkbaar niet doeltreffend was om dit te doen corrigeren. Het ziekenhuis was daardoor onvoldoende bestuurbaar.' 


\section{Ontwikkelingen governance semipubliek domein}

De implicaties van deze problematiek moeten ook worden bezien tegen de achtergrond van de aanscherping van de governance in het semipublieke domein en meer in het bijzonder de verdere professionalisering en toenemende verantwoordelijkheid van het bestuur en intern toezicht van zorgorganisaties. Onder verwijzing naar onder andere de invoering van het stelsel van integrale bekostiging wordt van overheidswege het belang benadrukt van 'een optimale inrichting van het bestuur, het interne toezicht en de betrokkenheid van direct belanghebbenden binnen zorginstellingen' hetgeen er toe noopt dat 'raden van bestuur hun eindverantwoordelijkheid voor kwaliteit en veiligheid van zorg ook echt waarmaken'. ${ }^{25}$ Om dat te bevorderen wordt een aantal concrete maatregelen voorgesteld, waaronder een aanscherping van de verantwoordelijkheden over en weer van bestuurders en toezichthouders en een krachtige aanpak van onbehoorlijk bestuur en wanbeleid. De Inspectie Gezondheidszorg en Jeugd (IGJ) zal voortaan vaker raden van toezicht betrekken in haar toezichthoudende taak op de kwaliteit en veiligheid van de zorg. Bovendien is een nieuw beleidskader ontwikkeld voor een actiever gebruik van de ministeriële aanwijzingsbevoegdheid om op grond van artikel 27 Wkkgz rechtstreeks in te grijpen als het bestuur tekortschiet in de uitoefening van zijn (zorginhoudelijke) taak of bij disfunctionerende toezichthouders. ${ }^{26}$ Daarnaast worden, mede naar aanleiding van het rapport van de Commissie-Halsema, ${ }^{27}$ de persoonlijke aansprakelijkheidsgronden en ontslagvoorzieningen voor bestuurders en toezichthouders in het semipublieke domein uitgebreid door het voorstel voor de Wet bestuur en toezicht rechtspersonen (WBTR) dat medio 2016 bij de Tweede Kamer is ingediend. ${ }^{28}$ Dit wetsvoorstel vormt 'de hoeksteen van de maatregelen ter verbetering van de kwaliteit van bestuur en toezicht bij verenigingen en stichtingen in semipublieke sectoren', en beoogt 'de regeling voor bestuur en toezicht bij de verschillende soorten rechtspersonen aan te vullen en te verduidelijken' maar daarmee wil het kabinet ook 'de drempel tot aansprakelijkstelling of ontslag van wanpresterende bestuurders en toezichthouders verlagen'. ${ }^{29}$ Het aansprakelijkheidsrecht wordt hier nadrukkelijk een gedragsmatige werking toegedicht, zowel preventief als repressief, om bestuurders en

25 Kamerstukken II 2014/2015, 32012, 23, brief van de minister en staatssecretaris van Volksgezondheid, Welzijn en Sport d.d. 22 januari 2015.

26 Kamerstukken II 2015/2016, 32012, 35, brief van de minister en staatssecretaris van Volksgezondheid, Welzijn en Sport d.d. 13 januari 2016: Goede zorg vraagt om goed bestuur - Beleidskader; alsmede het nieuwe Toezichtkader van de IGJ en de NZa 'Toezicht op Goed Bestuur', Heerlen/Utrecht: juli 2016; waarover terecht kritisch J.G. Sijmons, 'Over de 'open normen' van goed bestuur en handhaving na invoering van de Wkkgz', TvGR 2016, nr. 2, p. 84-91.

27 Advies Commissie Behoorlijk Bestuur, Een lastig gesprek, september 2013; waarover Kamerstukken II 2013/14, 28479, 69, Kabinetsreactie rapport Commissie Behoorlijk Bestuur.

28 Kamerstukken II 2015/16, 34491, Wijziging van het Burgerlijk Wetboek in verband met de uniformering en de verduidelijking van enkele bepalingen omtrent het bestuur en de raad van commissarissen van rechtspersonen (Wet bestuur en toezicht rechtspersonen); meer uitgebreid hierover: J.M. de Jongh, 'Bestuur en toezicht rechtspersonen in vogelvlucht', Ondernemingsrecht 2017/102, p. 568-577; E. Plomp, 'De Wet bestuur en toezicht rechtspersonen: een aanwinst voor de zorgsector' en C.H.C. Overes, 'Het wetsvoorstel Bestuur en toezicht rechtspersonen in relatie tot de onderwijssector', in: Preadviezen Vereeniging 'Handelsrecht' 2016, Zutphen: Uitgeverij Paris 2016, resp. p. 105-147 en p. 71-104.

29 Resp. Kamerstukken II 2015/16, 34491 (WBTR), 3, memorie van toelichting, p. 3 en p. 1; en Kamerstukken II 2013/2014, 33750 VI (Aansprakelijkheid van bestuurders en toezichthouders in semipublieke sectoren), p. 1. 
interne toezichthouders van semipublieke organisaties zoals zorginstellingen, te disciplineren. ${ }^{30}$

\section{Organisatie- en governancestructuur samenwerkingsmodel}

Omdat de vormgeving en implementatie van het MSB als nieuw samenwerkingsmodel van het collectief van vrijgevestigde medisch specialisten en ziekenhuis voornamelijk door fiscale criteria wordt beheerst en in de meeste gevallen onder tijddruk tot stand is gebracht, zijn deze governanceaspecten doorgaans maar beperkt geadresseerd tijdens het hectische wordingsproces. In de meeste gevallen is per 1 januari 2015 - formeel - een juridisch, fiscaal en financieel zelfstandig MSB tot stand gebracht en zijn pas later en soms noodgedwongen initiatieven ontplooid om de (afstemming van de) interne organisatie- en governancestructuur van deze nieuwe samenwerkingsvorm op onderdelen te verbeteren. Initieel kent het reguliere samenwerkingsmodel doorgaans twee of meer afzonderlijke bedrijfskolommen met ieder hun eigen bestuurlijke gremia, managementfuncties en eventueel nog separate toezichthoudende en medezeggenschapsorganen. Typerend kennelijk voor traditionele organisatie van de zorg waar de Task Force 'De juiste zorg op de juist plek' in algemene zin spreekt van 'silo's' met eigen specialisaties maar ook met eigen belangen, machtsposities en financiering. ${ }^{31}$ Bij veel ziekenhuizen heeft dit samenwerkingsmodel geresulteerd in een organisatie- en governancestructuur met:

$\mathrm{i}$ het vrijwel ongewijzigd handhaven van de bestaande rechts- en besturingsvorm van de ziekenhuisstichting als toegelaten instelling op grond van de WTZi met een raad van toezicht die belast is met het toezicht op de bestuurlijke leiding door een raad van bestuur onder wiens verantwoordelijkheid het operationeel management de bedrijfsvoering en de zorgverlening door de betrokken professionals organiseert;

ii de oprichting van een of meerdere zelfstandige MSB's ten behoeve van de vrijgevestigde medisch specialisten in de vorm van een coöperatie, maatschap of bv met eigen MSB-bestuur, directie of operationeel management, een algemene vergadering van deelnemende specialisten, meerdere organisatorische eenheden (vakgroepen of oude maatschappen) voor de verschillende specialismen met eigen vakgroepbesturen en -vertegenwoordigers voor de ledenraad van het MSB alsmede (de mogelijkheid van) een afzonderlijke raad van commissarissen voor het MSB;

iii de oprichting of revitalisering van een formele vereniging voor de vertegenwoordiging van de medisch specialisten in dienstverband (VMSD); en

iv een medezeggenschapsstructuur met reguliere inspraakorganen ten behoeve van de medewerkers (ondernemingsraad), patiënten (cliëntenraad) en de medisch specialisten (Vereniging Medische Staf en/of MSB en VMSD).

\section{Meerledige overlegstructuur medische staf}

Het gemiddelde ziekenhuis kent dienovereenkomstig een uit meerdere geledingen samengestelde overlegstructuur voor de advisering en besluitvorming ten aanzien van bestuurlijke en zorginhoudelijke aangelegenheden als kwaliteit en veiligheid, strategische beleidsvorming alsmede organisatie en bedrijfsvoering. De contouren en onderlinge afbakening

30 L.G.H.J. Houwen, 'Herzieningswet bestuur en toezicht: effecten voor het semipublieke domein', TvOB 2014/4, p. 135-147.

31 Rapport Taskforce, De juiste zorg op de juiste plek, p. 49. 
van taken, bevoegdheden en verantwoordelijkheden van de betrokken gremia die aanvankelijk de nodige overlap maar ook regelmatig lacunes vertoonde, beginnen zich ondertussen wel steeds meer uit te kristalliseren. Om het overleg met de verschillende geledingen van de medische staf beter te stroomlijnen en zo veel mogelijk te clusteren naar één overleg-, advies- en besluitvormingsorgaan van alle medisch specialisten van het ziekenhuis, worden meerdere scenario's ontwikkeld. ${ }^{32}$ Dat zal overigens niet voor alle onderwerpen op gelijke wijze mogelijk of wenselijk zijn: over financiële en bedrijfsmatige aangelegenheden zoals productie- en prijsafspraken met de vrijgevestigde medisch specialisten zal uiteindelijk het MSB-bestuur beslissen, terwijl arbeidsvoorwaardelijke regelingen voor medisch specialisten in dienstverband doorgaans na overleg met het bestuur van de VMSD worden vastgesteld. ${ }^{33}$ Voor meer algemene aangelegenheden als kwaliteit en veiligheid van de integrale zorgverlening en het strategisch ziekenhuisbeleid, maar ook de organisatie van de zorgverlening en de bedrijfsvoering van het ziekenhuis, verdient een collectieve belangenbehartiging zowel vanuit het gezichtspunt van de medici als ziekenhuisoptiek echter sterk de voorkeur. De - fiscale - vrees voor het verlies van de 'ondernemersstatus' van de vrijgevestigde specialisten hoeft daar niet aan in de weg te staan als het MSB zelf maar over voldoende realiteitswaarde en substance beschikt.

In de meest vergaande variant worden VMS, MSB en VMSD daartoe formeel ondergebracht in één rechtspersoon, meestal een coöperatie waarvan alle medisch specialisten van het ziekenhuis lid zijn. Door middel van een interne differentiatie in stem- en financiële lidmaatschapsrechten en daarmee corresponderende afdelingen, kamers of separate vergaderingen van medisch specialisten in respectievelijk vrije vestiging en dienstverband worden aan 'iedere te onderscheiden groep van specialisten' eigenstandige bevoegdheden toegekend ten aanzien van de onderwerpen die deze groepen specifiek regarderen. Zo wordt de ultieme besluitvorming omtrent financiële aangelegenheden als het vaststellen en wijzigen van de collectieve samenwerkingsovereenkomst, het interne verdeelmodel, de honorariumomzet en de winstaanspraken in de statuten van deze gemeenschappelijke coöperatie doorgaans uitdrukkelijk voorbehouden aan de vergadering van vrijgevestigde medisch specialisten. Deze differentiatie in de toebedeling van bevoegdheden klinkt statutair eveneens door in de samenstelling, taakverdeling, bevoegdheden en stemrechtverhouding bij de besluitvorming (door individuele leden) van het coöperatiebestuur. Hetgeen overigens de collectieve verantwoordelijkheid van alle medische bestuursleden voor het algemeen, financieel en strategisch beleid van de coöperatie onverlet laat, maar hoogstens tot individuele disculpatie bij persoonlijke aansprakelijkstelling aanleiding kan geven. ${ }^{34}$ Indachtig deze gedifferentieerde taak- en bevoegdheidsverdeling vindt vervolgens zo veel mogelijk gezamenlijk overleg plaats met de ziekenhuisbestuurders en op onderdelen eventueel besluitvorming door het coöperatiebestuur dat daartoe dan, na voorafgaande goedkeuring en/of raadpleging van de onderscheiden groepen van medisch specialisten, door de leden van de coöperatie is 'gemandateerd'.

32 Vgl. ook Federatie Medisch Specialisten, Factsheet creëren één aanspreekpunt voor de raad van bestuur.

33 Arbeidsvoorwaarden Medisch Specialisten 2018: artikel 8.2.3 hoofdstuk 8 (Statuut medisch specialisten in dienstverband).

34 Art. 2:9 BW; vgl. in deze zin ook: Asser/Maeijer \& Kroeze 2-I* 2015, nrs. 198-203. 
Een vergelijkbare systematiek wordt ook wel gehanteerd in ietwat complexere federatieve verenigingsstructuren waarvan de onderscheiden rechtspersonen MSB, VMSD en VMS als zodanig lid zijn. Het meervoudig samengestelde federatiebestuur behartigt dan de collectieve belangen van deze verschillende ledengroeperingen van de federatie op financieel, arbeidsvoorwaardelijk, strategisch en kwalitatief gebied. Afhankelijk van de mate waarin de verschillende geledingen als afzonderlijke rechtspersonen statutair bevoegdheden hebben 'overgedragen' aan dit federatiebestuur kan vervolgens overleg, advisering of zelfs gezamenlijke besluitvorming met de raad van bestuur plaatsvinden op deze gebieden.

Minder vergaand geformaliseerde initiatieven om één gemeenschappelijke overlegtafel te creëren kan de VMS ten slotte zelf initiëren via een paritair samengesteld stafbestuur met vertegenwoordigers vanuit het MSB en de VMSD of het feitelijk inrichten van een gezamenlijke vergadering met afgevaardigden van het MSB- en VMSD-bestuur die de raad van bestuur adviseert over ziekenhuisbrede aangelegenheden op het gebied van kwaliteit, veiligheid en strategische beleidsvorming.

Door middel van deze geformaliseerde coöperatieve en federatieve verenigingsstructuren of informele overlegfora worden de gefragmenteerde belangenbehartiging en de bestuurlijke en zorginhoudelijke inbreng vanuit de medische staf weer meer centraal gecoördineerd. Dat markeert een belangrijke fase in de verdere ontwikkeling en professionalisering van het MSB en de positionering van de medische staf in het algemeen. De beraadslagingen aan deze juridisch of feitelijk georganiseerde overlegtafels kunnen betrekking hebben op alle ziekenhuisaangelegenheden, maar bij de daadwerkelijke advisering en besluitvorming wordt hier inhoudelijk nog regelmatig gedifferentieerd naar onderwerp (strategie, kwaliteit en veiligheid, productie- en prijsafspraken en arbeidsvoorwaarden) in relatie tot de betreffende doelgroep van betrokken specialisten. Afhankelijk van de formele bevoegdheidstoedeling in een ziekenhuisbrede specialistencoöperatie of de mandatering in meer complexe federatieve verenigingsstructuren kunnen dergelijke achterbanraadplegingen dan alsnog belemmerend of vertragend werken. Daarenboven dient men zich te realiseren dat al deze, meer of minder formalistische structuren, primair gericht zijn op het stroomlijnen van de interne verhoudingen binnen de medische staf en daar vooral gericht zijn op het bevorderen van het collectief door een verdere ontschotting van de verschillende disciplines, vakgroepen en/of bestaande maatschappen met een zekere mandatering van het coöperatie-, staf- of federatiebestuur voor het overleg en de eventuele onderhandelingen met de raad van bestuur van het ziekenhuis. Daadwerkelijke bestuurlijke participatie en een volwaardige integratie in de ziekenhuisorganisatie vergen evenwel verdergaande maatregelen.

\section{Meervoudige besturing ziekenhuisorganisatie}

MSB-vorming resulteert normaliter in meerdere bestuurlijke en operationele gremia binnen één ziekenhuisorganisatie. Naast de wettelijk voorgeschreven bestuurlijke en toezichthoudende organen van de toegelaten instelling voor medisch-specialistische zorg, de raad van bestuur en de raad van toezicht van de ziekenhuisstichting, fungeert meestal een betrekkelijk autonoom MSB-bestuur, directie of management en een algemene leden- of maatschapsvergadering met doorgaans een afzonderlijke vertegenwoordiging vanuit de verschillende vakgroepen ten behoeve van het MSB. In verband met deze meervoudige besturingsproblematiek wordt op stichtingsniveau, naast laagdrempelige vormen met een 
informeel bestuurlijk overlegmodel of een meer geformaliseerd afstemmingsoverleg in bijvoorbeeld een gezamenlijk 'bestuurslab' respectievelijk periodiek 'besturenberaad' tussen (de voorzitters van) de raad van bestuur en het MSB-bestuur, regelmatig geëxperimenteerd met varianten van 'co-bestuur'. Als modaliteiten van dit wat onbepaalde besturingsmodel, wordt onder andere gerefereerd aan de praktiserend medicus als parttime statutair bestuurder van het ziekenhuis of alternatieve bestuursvormen met een zogenoemd executive committee. ${ }^{35}$ In de algemene governancepraktijk is de laatstgenoemde bestuursvariant geen onbekend fenomeen en deze wordt inmiddels bij meer dan de helft van de beursgenoteerde onderneming gehanteerd. Deze bestuursvorm is in het verleden onder benamingen als 'bestuurscollege' of 'bestuursteam' met wisselend succes al eerder door enkele ziekenhuizen beproefd. Statutaire ziekenhuisbestuurders geven hier samen met MSBbestuurders en/of directieleden van het ziekenhuis via een separaat gremium, zoals een 'bestuursraad' of 'directiecomité', gezamenlijk leiding aan het ziekenhuis. In de praktijk gebeurt dat op uiteenlopende wijze met verschillende taken, bevoegdheden en verantwoordelijkheden van de betrokken bestuurders en directieleden. Dergelijke vormen van bestuurs- en managementparticipatie van praktiserende medisch specialisten kunnen onmiskenbaar voordelen bieden, zoals inbreng van specifiek medische expertise, bestuurlijke flexibiliteit en efficiency, meer begrip en betere afstemming van ieders belangen, intensieve betrokkenheid en breder draagvlak onder medisch specialisten. ${ }^{36}$ Maar deze hybride besturingsvormen worden ook geconfronteerd met ingewikkelde governancevraagstukken en knelpunten die in de praktijk aanleiding (kunnen) geven tot ernstige bestuurlijke crisis en problematische medezeggenschapsdiscussies. ${ }^{37}$ Nog daargelaten dat de Wet normering topinkomens hier roet in het eten kan gooien, althans vooraf de krenten uit de pap kan halen indien de betrokken medici voor dit deel van hun bestuurlijke werkzaamheden formeel worden gekwalificeerd als 'topfunctionaris' in de zin van artikel 1.1 onder $\mathrm{b}$ jo. artikel 1.3 lid 1 onder d WNT, hetgeen bij statutair aangestelde parttime bestuurders alleszins geïndiceerd zal zijn.

\section{Belangenverstrengeling co-bestuur}

Belangrijk aandachtspunt bij besturingsmodellen met dergelijke vormen van co-bestuur vormt de (schijn van) belangenverstrengeling die veelal (latent) aanwezig is. Vrijgevestigde medisch specialisten maken hier als (bestuurs)lid van het MSB tevens deel uit van de statu-

35 Vgl. over deze bestuursvorm in het algemeen: Ch.E. Honée, 'Het Executive Committee, haken en ogen aan een nieuwe trend', Ondernemingsrecht 2014/23, p. 119-127 en 'Governance aspecten van het Executive Committee, en de vraag: waar staan zijn leden?', Ondernemingsrecht 2018/21, p. 125-134; M.C.M. Brandjes, 'Executive Committees. Valt er wat te regelen?', in: Jaarboek Corporate Governance 2014-2015, Deventer: Kluwer 2014, p. 133-140; alsmede S.H.M.A. Dumoulin, 'Het Executive Committee; over bestuur en toezicht, vennootschap en onderneming', Ondernemingsrecht 2017/63, p. 363-375.

36 A.H. Goodall, 'Physiciaan-leaders and hospital performance: is there an association?', Social Science E Medicine 73 (2011), p. 535-539; F. de Grave, D. Kruger en C. Hilders, 'Waarom medisch leiderschap?', in: Artsen met verstand van zaken, Utrecht: De Tijdstroom 2016, p. 161-165; 'Why The Best Hospitals Are Managed bij Doctors', Harvard Business Review 27 december 2016; M. Ott en H. Beijer, 'Arts als parttime-bestuurder is win-win', Medisch Contact 2014, p. 1269-1271.

37 Recent nog: Aanhangsel Handelingen II 2017/18, 80, Antwoorden op de vragen van Kamerlid Rutte over bericht 'Arts doet greep naar de macht' Ziekenhuisgroep Treant; Inspectie voor Gezondheidszorg, Instelling verscherpt toezicht Ziekenhuis Gelderse Vallei d.d. 22 mei 2017; waarover B. Rombout, 'Bedrijfsmodel lost conflict niet op', BoardRoom Zorg 2017/04, p. 8-12. 
taire raad van bestuur van het ziekenhuis of nemen als medisch lid dan wel directeur van de bestuursraad respectievelijk het directiecomité deel aan (onderdelen van) de beraadslagingen alsmede de (voorbereiding en uitvoering van de) besluitvorming van de raad van bestuur over strategische, financiële, bedrijfsmatige en andere bestuurlijke aangelegenheden van het ziekenhuis. Omdat de specifieke (financiële) deelbelangen van het MSB niet altijd parallel hoeven te lopen met het integrale ziekenhuisbelang, kan vanwege deze bestuurlijke ziekenhuisfunctie in combinatie met het lidmaatschap van het (bestuur van het) MSB van de betrokken medisch specialist sprake zijn van een tegenstrijdig belang in de zin van de wet (art. 2:129/239 lid 6 BW en art. 2:9 lid 5 wetsvoorstel WBTR) en par. 2.6 van de Governancecode Zorg 2017. Vooropgesteld zij, dat de enkele omstandigheid dat een medische co-bestuurder direct of indirect persoonlijke belangen heeft bij het (financiële) reilen en zeilen van het MSB nog niet automatisch hoeft te leiden tot de kwalificatie van een tegenstrijdig belang, zolang deze persoonlijke belangen maar parallel blijven lopen aan het ziekenhuisbelang. Evenmin hoeven de functionele incompatibiliteiten van artikel 2.6.2 GCZ 2017 op voorhand in de weg te staan aan een partiële personele unie van ziekenhuisen MSB-bestuur: het MSB kan weliswaar bezwaarlijk als dochter- of groepsmaatschappij van het ziekenhuis worden gekwalificeerd, maar hiermee onder omstandigheden wel 'anderszins nauw verbonden zijn'. Van een tegenstrijdig belang is volgens vaste jurisprudentie sprake indien, kort samengevat, de betrokken bestuurder door de aanwezigheid van een persoonlijk belang niet in staat moet worden geacht om het belang van de rechtspersoon en de daarmee verbonden organisatie te bewaken op een wijze die van een integer en onbevooroordeeld bestuurder mag worden verwacht. Daadwerkelijke benadeling is daarvoor geen direct vereiste: voldoende is dat de betrokken bestuurder te maken heeft met zodanig onverenigbare belangen dat in de context van het concrete geval in redelijkheid betwijfeld kan worden of hij zich bij zijn handelen uitsluitend zal laten leiden door het belang van de rechtspersoon en de daaraan verbonden organisatie. Is dat het geval, dan mag de medische co-bestuurder op grond van de (toekomstige) wet en doorgaans ook de statuten van de ziekenhuisstichting inhoudelijk niet deelnemen aan het overleg en de besluitvorming door de raad van bestuur. ${ }^{38}$

De wettelijke regelgeving omtrent tegenstrijdig belang wordt verder uitgewerkt door aanvullende gedragsregels van de GCZ 2017. Artikel 2.6.1 formuleert hier als uitgangspunt dat elke vorm van persoonlijke bevoordeling, belangenverstrengeling en ieder tegenstrijdig belang van bestuurders met de zorgorganisatie wordt voorkomen en de schijn hiervan wordt vermeden. Voor de begripsmatige interpretatie en contextafhankelijke invulling van deze integriteitsbepaling kan, zo zou ik menen, inhoudelijk aansluiting worden gezocht bij de wettelijke tegenstrijdigbelangregeling. Door de governancebepalingen van de code worden vervolgens preventieve maatregelen aangereikt om (de schijn van) belangenverstrengeling in een zo vroeg mogelijk stadium te voorkomen en te waarborgen dat bestuurders en toezichthouders van zorgorganisaties op de juiste wijze omgaan met mogelijke (potentiële) tegenstrijdige belangen. Deze procedurele waarborgen voor een zorgvuldige en inte-

38 HR 29 juni 2007, JOR 2007/169, m.nt. Leijten (Bruil); HR 14 oktober 2011, NJ 2012/110, m.nt. Van Schilfgaarde (Van Welie); HR 3 maart 2017, JOR 2017/84 m.nt. Leijten (Storteboom); Rb. Rotterdam 5 juli 2017, JOR 2017/226, m.nt. Van Thiel (Humanitas); OK 22 december 2017, ECLI:NL:GHAMS:2017:5354 (Intergamma) en ten slotte OK 30 april 2018, ECLI:NL:GHAMS:2018:1465 (DeSeizoenen). 
gere besluitvorming worden meestal in de reglementen van zowel de raad van bestuur als raad van toezicht van het ziekenhuis vastgelegd en impliceren in ieder geval dat elke vorm of schijn van belangenverstrengeling aan de raad van toezicht wordt gemeld, daarover alle relevante informatie wordt verschaft en door de raad van toezicht wordt besloten hoe daarmee wordt omgegaan.

In de feitelijke ziekenhuiscontext van alledag is het evenwel twijfelachtig of met dergelijke, voornamelijk procedurele maatregelen (de schijn van) belangenverstrengeling bij medische co-bestuurders wel in voldoende mate kan worden voorkomen. Zolang binnen een ziekenhuisorganisatie meerdere - organisatorisch, bedrijfseconomisch, financieel en fiscaal - zelfstandige bedrijven opereren, blijft het risico van (potentiële) belangenconflicten structureel aanwezig. ${ }^{39}$ Dat vormt dan weer een aansporing voor het nog verder optuigen van de formele governancestructuur met aanvullende preventieve maatregelen in statuten en reglementen om voor deze specifieke situatie zo veel mogelijk transparantie en, zo nodig met raadpleging van externe deskundigen, goedkeuring van de raad van toezicht, gedocumenteerde verantwoording en verbodsbepalingen, een zorgvuldige en integere besluitvorming te waarborgen. ${ }^{40}$ Een strikte toepassing van de gedragsnormen van de governancecode waardoor (potentieel) geconflicteerde bestuurders of directeuren op geen enkele wijze betrokken mogen zijn bij transacties waar mogelijk tegenstrijdige belangen spelen, zoals van overheidswege kennelijk wordt voorgestaan, ${ }^{41}$ zou er zelfs toe kunnen leiden dat medische co-bestuurders helemaal niet mogen deelnemen aan het overleg en de besluitvorming omtrent een groot aantal bestuurlijke aangelegenheden die weliswaar het ziekenhuis betreffen maar ook op enigerlei wijze de deelbelangen van het MSB raken. Daarmee creëert de MSB-vorming een bestuurlijk integriteitsdilemma ten aanzien van mogelijke belangentegenstellingen omdat dit samenwerkingsmodel als zodanig geen intrinsieke gelijkgerichtheid van belangen kent.

\section{Verantwoordelijkheidsverdeling}

Daarnaast ontbreekt bij alternatieve bestuursvormen met een executive committee, zoals een bestuursraad of directiecomité, regelmatig een duidelijke afbakening van taken, bevoegdheden en verantwoordelijkheden van de medische co-bestuurders vanuit het MSB. De feitelijke en juridische positie wordt nog mistiger als het bestuurs- of directiereglement melding maakt van 'co-bestuurders' die deel uitmaken van een 'bestuurlijk overlegorgaan met een uitsluitend voorbereidende en uitvoerende functie' dat evenwel 'de facto' de func-

39 Of zoals de federatie- en stafvoorzitter van de medische staf van het Utrechtse Diakonessenhuis het onlangs bij gelegenheid van de vorming van de Federatie Medische Staf Diakonessenhuis kernachtig verwoordde in zijn slotverklaring: 'Er zijn nu eenmaal tegenstrijdige belangen.' ('Uit één mond spreken', Zorgvisie Magazine 4, april 2018, p. 16-19).

40 Over gedragsnormen en preventieve maatregelen bij belangenverstrengeling in meer algemene zin: A.F.J.A. Leijten, 'Een tegenstrijdigbelangregeling ontwerpen', WPNR 2017/7173, p. 953-960; en Chr.M. Stokkermans, 'Tegenstrijdig belangregeling bij de rechtspersoon? Realistisch aanpakken', WPNR 2017/7173, p. 942-952: 'Structurele risico's verdienen doorgaans structurele maatregelen', alsmede de bijdrage naar aanleiding van recente jurisprudentie van M. Koelemeijer, 'Commissaris en tegenstrijdig belang', TvOB 2018/3, p. 58-64.

41 Kamerstukken II 2015/16, 23235 (Thuiszorg), 164, brief van de staatssecretaris van Volksgezondheid, Welzijn en Sport d.d. 5 augustus 2016 inzake de conclusies en vervolgonderzoeken Alliade, p. 3: 'Cliënten moeten volledig kunnen vertrouwen op de integriteit van zorgaanbieders. Het laten bestaan van een situatie waarin steeds weer de vraag gesteld kan worden welk belang hiermee wordt gediend, ondermijnt dit vertrouwen.' 
tie van 'dagelijks bestuur' van het ziekenhuis vervult. Dat laatste veronderstelt weer een zekere vorm van delegatie of mandatering van bestuurstaken en -bevoegdheden. Het legt ook een onevenwichtigheid in de verantwoordelijkheids- en aansprakelijkheidsverdeling bloot: medische 'co-bestuurders' zonder een statutaire grondslag worden op grond van hun feitelijke positie en medische expertise wel intensief betrokken bij het inhoudelijk overleg en de feitelijk besluitvorming omtrent bestuurlijke, zorginhoudelijke, strategische, bedrijfseconomische en financiële ziekenhuisaangelegenheden, zonder dat zij daarvoor formeel ('eind')verantwoordelijkheid dragen en normaliter evenmin op gelijke wijze als statutaire bestuurders persoonlijk aansprakelijk kunnen worden gehouden. De collectieve en individuele verantwoordelijkheid voor de bestuurlijke taakvervulling en in het bijzonder de kwaliteit en veiligheid van de medische zorgverlening, rust wettelijk immers op de statutaire bestuurders van het ziekenhuis. ${ }^{42}$ Dat wordt doorgaans ook nog eens met zoveel woorden gememoreerd in de samenwerkingsovereenkomst tussen ziekenhuis en MSB. Verder kent de vennootschapsrechtelijke aansprakelijkheidsbepaling van artikel 2:151/261 BW voor functionarissen die feitelijk bestuursdaden verrichten en daarvoor op dezelfde voet aansprakelijk zijn als bestuurders, ${ }^{43}$ (nog steeds) geen pendant voor reguliere ziekenhuizen in de stichtingsvorm. ${ }^{44}$ Medische co-bestuurders zouden daarmee dus vergaande bestuurlijke invloed krijgen zonder evenwel dienovereenkomstig verantwoordelijkheid te dragen laat staan op gelijke voet als de statutaire ziekenhuisbestuurders met persoonlijke aansprakelijkheid geconfronteerd kunnen worden.

\section{Positionering raad van toezicht ziekenhuisstichting}

Door deze onevenwichtigheid in het besturingsmodel, en in meer algemene zin de opzet en bestuurlijke systematiek van het MSB als zelfstandig collectief van vrije beroepsbeoefenaren, kan bovendien de positie van de raad van toezicht van het ziekenhuis in het gedrang komen. Op grond van de governancecode en de wettelijke taakomschrijving van de raad van commissarissen is het toezichthoudend orgaan verantwoordelijk voor het toezicht op het beleid van het bestuur en de gang van zaken in de zorgorganisatie, inclusief het integrale proces van medische zorgverlening, en kan daartoe informatie inwinnen bij de diverse functionarissen en organen van de zorgorganisatie. ${ }^{45}$ Deze verantwoordelijkheid, zo overweegt de NZa, strekt zich in het samenwerkingsmodel niet uit tot het MSB als los van het ziekenhuis staande entiteit, maar ziet enkel op de samenwerkingsafspraken met de raad van bestuur. Vanwege de grotere afstand tot het bestuurlijk, financieel-economisch en juridisch zelfstandige MSB kunnen de interne toezichthouders het primaire proces dat in belangrijke mate door de daaraan verbonden medisch specialisten wordt verzorgd slechts

42 Art. 2:9 BW jo. art. 1-4 Wkkgz jo. par. 5.1 GCZ 2017; alsmede Toezichtkader IGJ en NZa 'Toezicht op Goed Bestuur' (juli 2016) p. 7-12.

43 Volgens Honée is dit de belangrijkste aansprakelijkheidsgrondslag voor niet-statutaire leden van een exco: Ch.E. Honée, 'Aansprakelijkheid van niet-statutaire leden van de executive committee - als waren het bestuurders?', in: Aansprakelijkheid van bestuurders en commissarissen, Nadere terreinverkenning in een uitdijend rechtsgebied, Serie vanwege het Van der Heijden Instituut, nr. 140, Deventer: Wolters Kluwer 2017, p. 111-127.

44 In het voorgestelde wetsontwerp bestuur en toezicht rechtspersonen worden deze bepalingen uit het nv- en bv-recht weliswaar overgeheveld naar art. 9 lid 6 van de algemene bepalingen van Boek 2 BW, maar tegelijkertijd gerelateerd aan en opmerkelijk genoeg dus beperkt tot enkel de statutaire belet- en ontstentenisregeling.

45 Vgl. art. 6.1 jo. art. 6.4.3 GCZ 2017 en art. 11 lid 2 wetsvoorstel WBTR. 
indirect - via de invloed van de raad van bestuur op de werking van de samenwerkingsovereenkomst - en informeel - via hun contacten met het (bestuur van het) MSB - volgen. ${ }^{46}$ Overwegingen die, hoe begrijpelijk ook, op gespannen voet staan met de toezichthoudende verantwoordelijkheid voor de integrale zorgverlening door het ziekenhuis als toegelaten zorgorganisatie en formele contractspartij van de zorgverzekeraars. Maar tegelijkertijd een duivels dilemma adresseren omdat in het kader van de MSB-vorming nu eenmaal 'governancestructuren met een rechtstreeks (intern) toezicht op de integrale zorgverlening en de totale bedrijfsvoering ontbreken met een verhoogd risico dat de rvt meer op afstand van het primaire zorgproces komt te staan' en 'toezicht op informele basis richting medisch specialisten binnen het MSB (...) hiervoor onvoldoende' is, aldus de conclusies uit het onderzoek van Tias. ${ }^{47}$ Het aanstellen van een eigen raad van commissarissen voor het MSB ziet de NZa evenmin als wenkend perspectief, daar dit zou leiden tot een nog complexere governancestructuur en een ongewenste verzuiling binnen de zorgverlenende organisatie als geheel'. Vooralsnog worden als mogelijke oplossingen voor deze governanceproblematiek aangedragen: (i) het op vrijwillige basis verschaffen van meer openheid van zaken door het MSBbestuur; (ii) het zo veel mogelijk door tussenkomst van de raad van bestuur informeel volgen van het MSB; en ten slotte (iii) het feitelijk vergroten van de grip van de raad van toezicht op de samenwerkingsovereenkomst. ${ }^{48}$ Dergelijke maatregelen zijn voornamelijk gericht op informele informatieverschaffing zonder dat daar structurele bevoegdheden voor de raad van toezicht aan verbonden zijn. Het is nog maar zeer de vraag of raden van toezicht van ziekenhuizen op deze - indirecte en informele - wijze genoeg zicht op (de kwaliteit en veiligheid van) het primaire zorgproces kunnen verkrijgen en voldoende doorzettingsmacht kunnen genereren om hun toegenomen verantwoordelijkheden daadwerkelijk te effectueren. MSB-bestuurders zijn immers, evenmin als medische co-bestuurders zonder statutaire basis, ${ }^{49}$ als zodanig verantwoording verschuldigd aan de raad van toezicht en worden doorgaans ook niet door het toezichthoudend orgaan van het ziekenhuis benoemd, geschorst of ontslagen. Daarvoor ontbreekt, vooralsnog, een adequate governancestructuur hetgeen de noodzaak van een verdere doorontwikkeling van de huidige ziekenhuisorganisatie onderstreept.

\section{Toekomstperspectief governance ziekenhuisorganisatie}

De verworvenheden van het MSB hebben, als gezegd, vooral betrekking op de interne verhoudingen binnen de medische staf: MSB-vorming bevordert met name de bestuurlijke, financiële en zorginhoudelijke integratie van het collectief van vrije beroepsbeoefenaren. De gelijkgerichtheid binnen (de onderscheiden groepen van specialisten van) de medische staf kan hierdoor worden verbeterd. In een volgende ontwikkelingsfase zou idealiter een verdergaande integratie van (het vrijgevestigde smaldeel van) de medische professie door

46 NZa Monitor integrale bekostiging, p. 40 en p. 44-46.

47 Tias-rapportage Integrale bekostiging en governance, p. 41 en 36.

48 NVTZ en Federatie Medisch Specialisten, Factsheet Relatie tussen de RvT van het ziekenhuis en het MSB, zulks onder verwijzing naar de NZa Monitor integrale bekostiging, p. 47 en p. 50.

49 Vgl. over de verhouding tussen het toezichthoudend orgaan en de exco ook par. 2.1.3 jo. 2.3.1 Corporate Governance Code 2016; en Ch.E. Honée, 'Governance aspecten van het Executive Committee, en de vraag: waar staan zijn leden?', Ondernemingsrecht 2018/21, p. 131-133. 
middel van daadwerkelijke participatie, zowel individueel als collectief, in de totale ziekenhuisorganisatie geïndiceerd zijn. Afhankelijk van de concrete vorm en inhoud kan het alignement van ziekenhuis en medische staf daardoor aanmerkelijk worden bevorderd.

\section{Intrinsieke gelijkgerichtheid}

Participatie van medisch specialisten kan op verschillende niveaus worden gerealiseerd: operationeel in de vorm van duaal management van vakgroepen of afdelingen, bestuurlijk in de hiërarchische lijnorganisatie of strategische topstructuur, financieel in het exploitatieresultaat van (onderdelen van) de integrale bedrijfsvoering en ten slotte juridisch en economisch in de eigendomsstructuur van het ziekenhuis. De basis voor een dergelijke doorontwikkeling van het MSB binnen de ziekenhuisorganisatie is inmiddels stevig verankerd in het huidige regeerakkoord: 'Voor meer gelijkgerichtheid in het ziekenhuis stimuleren we dat medisch specialisten de stap maken naar het participatiemodel of loondienst. ${ }^{50} \mathrm{De}$ keuzevrijheid van de medisch specialist als autonoom verantwoordelijk professional om zelf te opteren voor het vrije beroep of een arbeidsrechtelijk dienstverband dan wel academische aanstelling vormt hier naar mijn mening een belangrijk uitgangspunt. Deze keuzevrijheid is onlangs (her)bevestigd door het Onderhandelaarsakkoord medisch-specialistische zorg 2019 t/m 2022 waar als een van de inhoudelijke randvoorwaarden voorop wordt gesteld: 'Om de benodigde focus te richten op de transformatie naar de juiste zorg op de juiste plek zal gedurende de kabinetsperiode Rutte III de vrije keuze voor medisch specialisten om te werken in dienstverband of als vrije beroepsbeoefenaar gehandhaafd blijven en zullen medisch specialisten en gelijkgestelde beroepsbeoefenaren, te weten klinisch chemici, klinisch fysici en ziekenhuisapothekers (voor zover zij als zodanig werkzaamheden verrichten) buiten de werkingssfeer van de Wet Normering Topinkomens blijven. ${ }^{51}$ Dat biedt ruimte en rust voor evenwichtige keuzes die minder door fiscale en financieeleconomische overwegingen worden gedomineerd, maar vanuit zorginhoudelijke en bestuurlijke optiek vooral gericht zijn op alignement van medisch specialisten en (bestuur en management van) het ziekenhuis. Intrinsieke gelijkgerichtheid ziet dan niet louter en alleen op financiële belangen, maar adresseert ook nadrukkelijk daarmee samenhangende thema's als zeggenschap en verantwoordelijkheid ten aanzien van de integrale zorginhoudelijke dienstverlening en de financiële bedrijfsvoering van het ziekenhuis.

\section{Integratie medisch specialisten}

De betrokkenheid van medisch specialisten bij de ziekenhuisorganisatie kan door een dergelijke benadering worden vergroot en een minder eendimensionaal (financieel), maar juist meer gelijkwaardig (zeggenschap) en wederkerig (verantwoordelijkheid) karakter krijgen. Dat veronderstelt een verdergaande integratie van de medische professie in de ziekenhuisorganisatie dan nu het geval is bij de meeste samenwerkingsvormen. In plaats van een voortschrijdende verzelfstandiging van (vrijgevestigde) medisch specialisten, zou de focus van het MSB naar mijn overtuiging meer gericht moeten zijn op het - onvoltooide - integratieproces in het ziekenhuis met als wenkend toekomstperspectief een gezamenlijke ziekenhuisorganisatie als onderdeel van een bredere lokale of regionale netwerkorganisatie 
met andere (eerstelijns)zorg- en welzijnsorganisaties. Voor een dergelijke integratie pleiten zowel interne overwegingen als externe ontwikkelingen in de curatieve sector, met name: een gematigde groei of zelfs krimp van het macrobudget voor medisch-specialistische zorg; de budgettaire effecten van integrale bekostiging en selectieve zorginkoop; het belang van volume- en kwaliteitseisen van beroepsverenigingen en zorgverzekeraars; (sub)specialisatie en concentratie mede in relatie tot de herpositionering van de eerstelijnszorg; toenemende comorbiditeit en de noodzaak van multidisciplinaire zorgverlening met integrale zorgpaden; de hogere eisen die door wetgeving en rechtspraak aan het functioneren van bestuurders en toezichthouders worden gesteld; een evenwichtige en doelmatige governancestructuur zonder onnodige bestuurlijke drukte; de centrale verantwoordelijkheid en aansprakelijkheid van het ziekenhuis; alsmede de urgentie van risicodragende eigen investeringen voor verbetering van de vermogenspositie van het ziekenhuis, mede gezien de afnemende (bereidheid tot) bancaire financiering en het grotere faillissementsrisico. ${ }^{52}$ De daarvoor noodzakelijke participatie van medisch specialisten in loondienst en vrije beroepsbeoefenaren kan in meerdere opzichten worden bevorderd: zowel ten aanzien van zeggenschap en verantwoordelijkheid op strategisch, bedrijfsmatig en zorginhoudelijk gebied als in financieel-economisch opzicht.

\section{Participatie medisch specialisten in dienstverband}

Voor medisch specialisten die op basis van een arbeidsrechtelijk loondienstverband werkzaam zijn in het ziekenhuis is hiervoor in 2012 in het zogenoemde Kaap Doorn Manifest al een eerste aanzet gegeven. ${ }^{53}$ De toenmalige beroeps- en brancheorganisaties van medisch specialisten en ziekenhuizen LAD, OMS en NVZ hebben daarin een gezamenlijke visie geformuleerd voor de vernieuwing van de arbeidsverhoudingen en -voorwaarden van medisch specialisten in dienstverband. Hun gezamenlijk perspectief richt zich, naast een pleidooi voor meer flexibiliteit, mobiliteit en persoonlijke ontwikkeling, vooral op een nauwere betrokkenheid en inspraak bij de besturing en het daadwerkelijk nemen van medeverantwoordelijkheid voor de strategische en financiële keuzes van de instelling alsmede de kwaliteit en kwantiteit van de medisch-specialistische zorg van het ziekenhuis.

Deze uitgangspunten zijn naderhand uitgewerkt in een apart Statuut van de vernieuwde AMS. ${ }^{54}$ Naast de afspraken over de individuele verantwoordelijk voor de patiëntbehandeling waarin de professionele autonomie van de medisch specialist voorop wordt gesteld, voorziet het Statuut onder andere in een regeling van medezeggenschap door de medische staf ten aanzien van het strategisch ziekenhuisbeleid waarbij nadrukkelijk naar consensus wordt gestreefd. Vanuit hun eigen positie dragen bestuur en medisch specialisten gezamenlijk verantwoordelijkheid voor de continuiiteit van de patiëntenzorg en voor een zo concurrerend mogelijk zorgaanbod. Voor zover het binnen zijn invloedssfeer valt, worden productievolume en omzet eveneens als medeverantwoordelijkheid van de medisch speci-

52 Meer uitvoerig over deze ontwikkelingen: Houwen, Van maatschappelijk belang, maatschappelijk belang als normatief governancemodel, p. 75-82; NZa, Eindrapport en beleidsbrief 'Risicoverkenning faillissementen van zorgverzekeraars en ziekenhuizen', Utrecht: juni 2015; en Onderzoeksrapportage EY: 'Onderzoek mogelijkheden tot bevorderen participatiemodel' d.d. 14 april 2017, p. 23-26 en p. 44-48.

53 NVZ, LAD en OMS, Kaap Doorn Manifest d.d. 23 november 2012.

54 Hoofdstuk 8. Statuut medisch specialisten in dienstverband, Arbeidsvoorwaarden Medisch Specialisten 2018, Hoofdstuk 15 CAO Ziekenhuizen 2017-2019. 
alist beschouwd. Tegen de achtergrond van de arbeidsrechtelijke gezagsverhouding wordt in dit Statuut ten slotte expliciet gerefereerd aan de bevoegdheid van het bestuur om aanwijzingen aan de individuele medisch specialist te geven over de kwaliteit en veiligheid en de organisatie van de zorg. Deze aanwijzingsbevoegdheid heeft geen betrekking op de medisch inhoudelijke zorgverlening aan de patiënten en kan, zo wordt nogmaals gememoreerd, evenmin als bij vrije beroepsbeoefenaren in de professionele autonomie van de medisch specialist met een loondienstverband treden. ${ }^{55}$ Het vormt wel de formele basis voor bestuur en raad van toezicht om hun bestuurlijke respectievelijk toezichthoudende verantwoordelijkheden daadwerkelijk te effectueren.

Voor het bevorderen van financiële betrokkenheid van medisch specialisten in dienstverband komen verschillende participatievormen in aanmerking. Het gaat hier dan voornamelijk om modaliteiten van werknemersparticipatie waarbij medisch specialisten met een civiel- en fiscaalrechtelijk loondienstverband op enigerlei wijze economisch participeren in het exploitatieresultaat van het ziekenhuis. Zo kent het OLVG-loondienstmodel een variabele prestatiebeloning waarbij de inkomsten van de medisch specialisten, naast een AMS-basissalaris, mede afhankelijk zijn van het integrale exploitatieresultaat en de kwaliteits- en efficiencywinst van het ziekenhuis. Operationeel worden de medische vakgroepen hier decentraal aangestuurd door leidinggevende specialisten die tezamen met de raad van bestuur het managementoverleg vormen. Alle medisch specialisten en daarmee gelijkgestelde beroepsbeoefenaren maken deel uit van een medische staf die door tussenkomst van het stafbestuur adviseert over de kwaliteit van de zorgverlening en (strategische) ziekenhuisbrede aangelegenheden en periodiek overleg voert met de raad van bestuur, raad van toezicht en overige gremia van het ziekenhuis. ${ }^{56}$ Samen met de structuurvoorschriften van het vernieuwde AMS-Statuut kan een dergelijke vorm van variabele prestatiebeloning de bestuurlijke, zorginhoudelijke en financiële integratie van medisch specialisten in dienstverband aanmerkelijk verbeteren. Op deze wijze wordt voorzien in een consistente en doelmatige organisatie- en governancestructuur met een meer evenwichtige verdeling van (mede)zeggenschap en daarmee corresponderende verantwoordelijkheden van respectievelijk de (individuele leden van de) medische staf en de bestuurlijke en toezichthoudende gremia van de geïntegreerde ziekenhuisorganisatie.

\section{Hybride participatievormen}

Financiële betrokkenheid waarbij medisch specialisten individueel of collectief investeren in vastgoed, medische apparatuur of andere bedrijfsmiddelen van het ziekenhuis kan economisch onder meer worden bewerkstelligd door winstdelende leningen waar een vaste of variabele rentecomponent aan verbonden is die geheel of gedeeltelijk afhankelijk is van het exploitatieresultaat van het ziekenhuis. Daarmee wordt nog geen risicodragend eigen vermogen ter beschikking gesteld, maar vindt financiering van het ziekenhuis door of van-

55 Een verplichting die overigens ook uit art. 4 lid 4 jo. art. 2 lid 2 Wkkgz voortvloeit; meer uitvoerig hierover: P. Bergkamp, 'Bestuurlijke verantwoordelijkheid voor disfunctionerende specialisten: professionele autonomie aan banden?', in: Governance en ondernemerschap in de zorg, Nieuwe bestuurlijke verantwoordelijkheden in de gezondheidszorg, Deventer: Kluwer 2010, p. 39-60.

56 A. Vahl, 'OLVG, Als het ziekenhuis goed draait, profiteren wij daar ook van', in: Participatie in praktijk, Magazine Federatie Medisch Specialisten, oktober 2016, p. 5-6. 
wege de medisch specialisten via vreemd vermogen plaats. Als alternatief kan in dat verband worden geopteerd voor converteerbare obligatieleningen die op termijn kunnen worden omgezet in risicodragend aandelen- of ledenkapitaal dan wel winstdelende certificaten van aandelen die aanspraak geven op het resultaat en vermogen van het ziekenhuis. Op die manier creëert men in wezen een overgangsvorm naar risicodragende financierings- en participatiemodellen, waarbij in de praktijk inmiddels voorzichtig wordt geëxperimenteerd met werknemersaandelen. De ziekenhuisstichting wordt in dat laatste geval omgezet in een bv waarvan doorgaans een minderheidsbelang wordt gehouden door een stichting-administratiekantoor (STAK) die op haar beurt certificaten van aandelen uitgeeft aan de deelnemende medisch specialisten. ${ }^{57}$ De betrokken specialisten worden daardoor wel (indirect) economisch gerechtigd tot het vermogen van het ziekenhuis, maar krijgen individueel geen directe zeggenschapsrechten en als collectief evenmin overwegende invloed op het strategisch, financieel en bedrijfsmatige ziekenhuisbeleid van de raad van bestuur. In de algemene vergadering kunnen zij wel, via het STAK-bestuur, meepraten en (indirect en groepsgewijs) aan de stemming deelnemen over de goedkeuring van dit bestuursbeleid, de vaststelling van de jaarstukken met de winstbestemming, benoeming en ontslag van de bestuurlijke en toezichthoudende functionarissen alsmede structuurvraagstukken zoals de inrichting van de statutaire organisatie en governance, fusies en het aangaan van samenwerkingsverbanden. Maar de dominante positie in de uiteindelijke besluitvorming van de ziekenhuisvennootschap blijft in de huidige context vooral bij externe meerderheidsaandeelhouders gesitueerd, zoals private investeerders of een daartoe speciaal voor het ziekenhuis opgerichte 'beheersstichting'. Dat geldt (voorlopig) ook voor eventuele winstrechten waar deze medisch specialisten eveneens van verstoken blijven: uitkeringen van dividenden of revenuen uit het exploitatieresultaat van ziekenhuizen zijn immers (nog steeds) niet toegestaan, waardoor ook de waarde van dergelijke (certificaten van) aandelen ongewis blijft. Althans, zolang het wetsvoorstel 'Vergroten Investeringsmogelijkheden in de medisch-specialistische zorg' niet definitief door het parlement is aangenomen en het verbod van winstoogmerk van artikel 5 lid 2 WTZi dus nog onverkort gelding behoudt voor deze instellingen voor medisch-specialistische zorg. ${ }^{58}$ Via alternatieve uitbestedings- en onderaannemingsconstructies, ${ }^{59}$ onder welke categorie overigens ook de

57 Vgl. K.D. Meersma, 'Rutte III en het medisch specialistisch bedrijf II', ZIP 2018/45, p. 17-18; en T.A.M. van den Ende, 'Governance in het ziekenhuis, Het participatiemodel als Haarlemmerolie?', Onderneming en Financiering 2017/25, p. 90-99.

58 Kamerstukken I 2013/14, 33168, A, Wijziging van de Wet toelating zorginstellingen en enkele andere wetten teneinde investeringsmogelijkheden in medisch-specialistische zorg te bevorderen: in de Kamerbrief van 13 juli 2018 (Winstuitkering door zorgaanbieders) hebben de bewindslieden van Volksgezondheid, Welzijn, Medische Zorg en Sport onder verwijzing naar dit wetsvoorstel en de voorgenomen novelle nader onderzoek ten behoeve van de bredere discussie en de politieke besluitvorming over winstuitkering in de zorgsector aangekondigd dat begin 2019 zijn beslag moet krijgen; vgl. over deze wettelijke belemmering voor financiële participatie van medisch specialisten ook Onderzoeksrapportage EY: 'Onderzoek mogelijkheden tot bevorderen participatiemodel', p. 31-34.

59 E.J. de Jongh en L.G.H.J. Houwen, 'Winstuitkering en uitbesteding van medisch-specialistische zorg', in: Financiering van zorginstellingen, Met speciale aandacht voor medisch-specialistische zorg, Deventer: Vakmedianet 2015, p. 203-221; met recentelijk nogmaals de legitimatie van overheidswege: 'Het staat een WTZi-toegelaten instelling echter vrij om anderen bij haar dienstverlening te betrekken, zoals een dochter van de WTZitoegelaten instelling of een derde partij.' (Kamerbrief d.d. 13 juli 2018, Winstuitkering door zorgaanbieders, p. 3). 
meeste MSB-verbanden moeten worden geschaard, zou men voor (onderdelen van) de ziekenhuiszorg financieel-economisch vergelijkbare effecten in de winstsfeer kunnen bewerkstelligen, maar 'voor de zorgpraktijk is deze structuur echter in sommige opzichten onnodig bezwarend en zijn de voorwaarden onvoldoende kenbaar', volgens recent onderzoek vanwege het ministerie van VWS. ${ }^{60}$

Daarenboven kan men in het kader van deze 'revival' van het werknemersaandeel ${ }^{61}$ in de curatieve sector vraagtekens plaatsen bij de duurzaamheid en legitimiteit van de speciaal daartoe opgerichte 'beheersstichting', waaraan in dit hybride participatiemodel een belangrijke positie toebedeeld wordt. Door een dergelijk vehikel raken immers niet alleen de aanspraken op (de revenuen van) een omvangrijk deel van het ziekenhuisvermogen structureel 'in de dode hand'62 maar verkrijgt het bestuur van de 'beheersstichting' als meerderheidsaandeelhouder dominerende zeggenschap in de ziekenhuisvennootschap terwijl de certificaathoudende medisch specialisten (via hun STAK) de besluitvorming hoogstens op enkele specifieke onderdelen kunnen blokkeren maar niet ziekenhuisbreed initiëren, laat staan integraal doorzetten. Het borgen van de maatschappelijke belangen van de zorgorganisatie kan daarvoor bezwaarlijk als dragende motivering strekken, want dat dienen de raad van bestuur en raad van commissarissen al op grond van de Governance Code Zorg 2017 zorgvuldig in de maatschappelijke doelstelling van de nieuwe ziekenhuisvennootschap zelf te verankeren en met name ook rechtstreeks en op alle niveaus van het ziekenhuis via de cultuur en het gedrag van de professionals, overige medewerkers en betrokken gremia van het ziekenhuis te bevorderen. ${ }^{63}$ Zolang dat nog niet voldoende stabiel in de nieuwe ziekenhuisorganisatie is geïnternaliseerd en daarvoor nog onvoldoende vertrouwen in de waarborgfunctie en doorzettingsmacht van de bestuurlijke vennootschapsorganen bestaat, kan een speciale 'beheersstichting' praktisch wellicht nog in een zekere behoefte voorzien. Hetgeen niet wegneemt dat door het enigszins fictieve karakter en de zweem van 'toezicht op toezicht', de legitimiteit van het bestuur en daarmee ook het bestaansrecht van deze 'beheersstichting' op termijn sterk kan eroderen.

Al deze modaliteiten met verschillende deelaspecten en een uiteenlopende fasering van financiële, organisatorische en bestuurlijke participatie vormen een voorzichtige aanzet tot een verdere integratie van de medische professie in de ziekenhuisorganisatie. Het zijn experimentele constructies die een tegenwicht vormen tegen de al dan niet openlijke roep om verdergaande verzelfstandiging van (het collectief van) medisch specialisten. Regelmatig appelleren zij echter nog aan verouderde duale organisatiestructuren en wordt krampachtig vastgehouden aan een formalistische verantwoordelijkheidsverdeling die niet meer spoort met de werkelijke zeggenschaps- en machtsverhoudingen in het ziekenhuis. Ondanks alle (optische) participatieve elementen resulteert deze paradox niet zelden in omslachtige en weinig transparante governancestructuren waarbij uiteindelijk geen sprake is van risicodragende financiering noch winst- of verantwoordelijkheidstoedeling aan de

60 Onderzoeksrapportage EY: 'Onderzoek mogelijkheden tot bevorderen participatiemodel', p. 50.

61 Vgl. hierover ook in algemene zin: A.R. Houweling en A.B.M. Soppe, 'Financiële werknemersparticipatie in Nederland: waar een wil is, is een (soms nog lange) weg. Een empirisch onderzoek naar werknemersparticipatie in Nederland', Tijdschrift Arbeidsrechtpraktijk, 2014/4, p. 204-213.

62 Asser/Rensen 2017, nr. 299.

63 Principe 1, 2, 5 en 6 resp. hoofdstuk A GCZ 2017. 
betrokken specialisten. In zoverre markeren deze hybride participatiemodellen vooral een overgangsfase naar meer duurzame en transparante vormen van intrinsieke betrokkenheid en, zo men wil, materieel eigenaarschap van medisch specialisten van de gezamenlijke ziekenhuisorganisatie.

\section{Materieel eigenaarschap}

Zorginhoudelijk is in veel ziekenhuizen inmiddels een vergaande mate van operationele en klinische integratie van de medisch specialisten in het primaire proces gerealiseerd: als uitvloeisel van een bewuste strategie of min of meer toevallige bijvangst van de MSB-vorming. ${ }^{64}$ Participatie vanuit bestuurlijke en financieel-economische optiek met een evenwichtige verdeling van bestuurlijke verantwoordelijkheden waarbij medisch specialisten daadwerkelijk worden betrokken in de infrastructuur van het ziekenhuis vormt dan een volgende ontwikkelingsfase van het nog (steeds) onvoltooide integratieproces. Dat geldt zowel voor de integrale bekostiging als de inrichting van het governancesysteem. Ten aanzien van beide aspecten heeft sinds 2015 een zekere mate van integratie plaatsgevonden. Op het gebied van de bekostiging heeft met name een externe integratie in de contractuele verhouding tussen het ziekenhuis en de zorgverzekeraars plaatsgevonden, omdat er nog maar één gezamenlijk tarief wordt gedeclareerd waarvan zowel het honorarium als de ziekenhuisomzet deel uitmaken. De interne integratie met betrekking tot de governance wordt volgens de besproken onderzoeksrapporten van Tias en NZa vooral zichtbaar binnen (het vrijgevestigde smaldeel van) de medische staf. In beide opzichten is een volgende fase geïndiceerd waarbij een volledige integratie tussen (de besturing en financiën van) de (vrijgevestigde) medisch specialisten én het ziekenhuis plaatsvindt zodat er één gezamenlijke ziekenhuisorganisatie ontstaat waarvan de medisch specialisten niet alleen zorginhoudelijk en organisatorisch maar ook financieel en bestuurlijk integraal onderdeel uitmaken. Dat kan, zoals gezegd, worden gerealiseerd via een loondienstverband met prestatiebeloning maar ook door middel van materieel (juridisch en/of economisch) eigenaarschap ('corporate ownership') van het ziekenhuis. Vrijgevestigde medisch specialisten die hechten aan hun ondernemersstatus zullen daartoe dan in de economische en/of juridische eigendomsstructuur van het ziekenhuis betrokken moeten worden. Vanuit ziekenhuisperspectief veronderstelt een dergelijke doorontwikkeling van het MSB een meer ingrijpend integratieproces waarbij de medische staf in de governancestructuur van het ziekenhuis wordt geïncorporeerd met een gelijktijdige samenvoeging van ziekenhuis en MSB in een gezamenlijke ziekenhuisorganisatie. ${ }^{65}$ Het MSB ontwikkelt zich dan tot een gezamenlijk medisch-specialistisch ziekenhuisbedrijf dat voor gemeenschappelijke rekening en risico integrale patiëntenzorg verleent. ${ }^{66}$ Daarmee worden twee doelstellingen beoogd: (i) een evenwichtige governancestructuur met daadwerkelijke gelijkgerichtheid van financiële en zorginhoudelijke belangen en wederzijdse betrokkenheid van medisch specialisten en zie-

Vgl. over deze ontwikkeling ook: Th.P.M. Schraven, 'Over governance in de zorg en de medisch specialist als eigenaar van het ziekenhuis', in: Governance in de zorg, Van inrichting naar inspiratie, van wetten naar waarden, $\mathrm{p}$. 61-74.

65 L.G.H.J. Houwen, 'Naar een nieuw ondernemingsmodel voor medisch specialisten', Nederlands Tijdschrift voor Geneeskunde, 2013/157.

66 Vgl. ook Raad voor de Volksgezondheid \& Zorg, 'Garanties voor kwaliteit van zorg', Advies 13/03, Den Haag 2013, p. 55-56. 
kenhuis; en (ii) materiële en formele zeggenschap met dienovereenkomstige collectieve en individuele verantwoordelijkheid van medisch specialisten voor de integrale medisch-specialistische zorg- en dienstverlening en de financiële exploitatie (met betrekking tot productie, omzet, kostenstructuur en vermogensontwikkeling) van de totale ziekenhuisorganisatie.

Een volwaardig participatiemodel dat als tegenhanger van de loondienstvariant materieel eigenaars- en ondernemerschap impliceert, kent drie wezenlijke elementen. Naast zorginhoudelijke en financieel-economische betrokkenheid, gaat het om gezamenlijke zeggenschap en ten slotte een evenwichtige verantwoordelijkheidsverdeling. De wijze waarop en de mate waarin deze elementen door medisch specialisten en ziekenhuis worden geadresseerd in een dergelijk participatiemodel, zijn sterk contextafhankelijk. Naast onder andere aard, omvang, functieprofiel en de lokale setting van het ziekenhuis zal daarvoor de strategische visie en ambitie maar bovenal de mate van ondernemerschap en risicobereidheid van het MSB respectievelijk de betrokken medisch specialisten bepalend zijn. Zo kan economische en/of juridische participatie betrekking hebben op de totale ziekenhuisorganisatie, maar bij aanvang van deze integratiefase voorlopig beperkt blijven tot specifieke onderdelen zoals afdelingen, vakgroepen of resultaatverantwoordelijke eenheden van het ziekenhuis. In dat geval worden deelactiviteiten van het ziekenhuis ondergebracht in een gezamenlijke joint venture, veelal een kapitaalvennootschap (bv) of een personenvennootschap (vof of commanditaire vennootschap), die op basis van gelijkwaardigheid en voor gezamenlijke rekening en risico bijvoorbeeld een obesitas- of oogkliniek dan wel een diagnostisch centrum exploiteren. De bestaande ziekenhuisstichting en de juridische verschijningsvorm van de betrokken collectieven van medisch specialisten blijven formeel in stand, maar zo'n samenwerkingsverband kan dan wel in een gefragmenteerd belangspectrum resulteren.

\section{'Doctor-owned hospital'}

Materieel eigenaarschap van medisch specialisten kan evenzeer betrekking hebben op de totale ziekenhuisorganisatie. Er ontstaat dan een zogenoemd 'doctor-owned hospital' dat zich vervolgens weer via een maatschappelijk ondernemingsmodel kan doorontwikkelen naar een lokale of regionale netwerkorganisatie. Een dergelijke economische en juridische participatie veronderstelt een integratie en omvorming van het MSB en de ziekenhuisstichting in een meer geschikte organisatie- en rechtsvorm voor het gezamenlijke ziekenhuis. De traditionele stichtingsvorm kan daartoe worden omgezet in een naamloze of besloten vennootschap respectievelijk coöperatie waarvan de deelnemende medisch specialisten rechtstreeks via individuele aansluitings- en dienstverleningsovereenkomsten of indirect via een speciaal daartoe opgericht collectief het aandeelhouderschap of lidmaatschap verwerven. Door inbreng van hun praktijk, goodwill of andersoortige kapitaalstortingen verkrijgen zij aanspraken op het vermogen en het financiële resultaat van het gezamenlijke ziekenhuis alsmede formele zeggenschapsrechten in de aandeelhouders- of ledenvergadering. Het aandeelhouder- of lidmaatschap impliceert aldus materieel eigenaarschap ('cor- 
porate ownership') van de totale ziekenhuisorganisatie. ${ }^{67}$ Voor het vaststellen van de hoogte van hun vermogens- of kapitaalinbreng zal in financieel opzicht een waardebepaling van het ziekenhuis nodig zijn. Als men daarvoor de gebruikelijke (Discounted Cash Flow of Dividend Discount Model) waarderingsmethoden hanteert, hoeft de prijs voor deze aandelen waarschijnlijk geen onoverkomelijke bezwaren voor risicodragende participatie van medisch specialisten in het gemiddelde ziekenhuis op te leveren. ${ }^{6}$ De daaruit voortvloeiende revenuen kunnen vervolgens door de deelnemende specialisten als een (combinatie van) ondernemersbeloning (winstuitkering) en/of arbeidsbeloning (honorarium of managementfee via ieders persoonlijke bv) worden gerealiseerd. Deze vennootschappelijke of coöperatieve ondernemingsstructuren veronderstellen wel de wettelijke mogelijkheid om op een solide wijze risicodragend kapitaal te investeren in instellingen voor medisch-specialistische zorg die daarvoor ook een redelijke vergoeding voor deze kapitaalinbreng mogen uitkeren. ${ }^{69}$

\section{Maatschappelijke netwerkorganisatie}

Op deze wijze bevordert men, ook van overheidswege, het 'doctor-owned hospital' waarbij ondernemende medisch specialisten als aandeelhouder van een ziekenhuisvennootschap of via het lidmaatschap van een ziekenhuiscoöperatie formele zeggenschap hebben over en uiteindelijk verantwoordelijkheid dragen voor een gezamenlijke ziekenhuisexploitatie. Het biedt bovendien perspectieven voor de verdere ontwikkeling van een maatschappelijk ondernemingsmodel, waarbij het ziekenhuis en de medisch specialisten op een flexibele en doelmatige wijze samenwerken in of ten behoeve van regionale allianties of medische netwerkorganisaties waar de Task Force 'De juiste zorg op de juiste plek' aan refereert. ${ }^{70}$ Voor een aantal van zulke initiatieven met een coördinerende functie voor het ziekenhuis zou dan met name de coöperatie de aangewezen rechtsvorm zijn. Coöperatieve organisatiestructuren zijn als zodanig niet gericht op financieel rendement voor hun leden, maar op het ondernemen ten behoeve van hun achterban teneinde daardoor ledenwaarde te creëren. Dat sluit goed aan op de basisprincipes van de GCZ 2017 waarin de maatschappelijke doelstelling en legitimatie, namelijk kwalitatief goede zorgverlening ten behoeve van alle interne en externe belanghebbenden, voor de zorgorganisatie centraal staat. Via de lidmaatschapsstructuur van de coöperatie kunnen, naast de betrokken medisch specialisten, ook andere zorg- en welzijnsorganisaties en -ondernemingen, poliklinische centra, zorggroepen of andere (groepen van) stakeholders, op een relatief eenvoudige en gedifferentieerde wijze participeren in een coöperatieve ziekenhuisorganisatie. Voor de diverse categorieën van leden kan dan statutair worden voorzien in bijzondere lidmaatschapsvormen met uiteenlopende (financiële) bijdragen, gedifferentieerde (zeggenschaps)rechten en verplichtingen of aanspraken op de uitkering van een positief exploitatiesaldo. De coöpe-

67 Uitvoerig over dit participatiemodel: L.G.H.J. Houwen, 'Rechtsvorm en governance van privaat gefinancierde zorgondernemingen', in: Financiering van zorginstellingen, Met speciale aandacht voor medisch-specialistische zorg, Deventer: Vakmedianet 2015, p. 161-183 en TvOB 2016-6, p. 175-187.

68 Vgl. hierover: J. Plus, 'Waardering van (investeringen in) de zorgonderneming', in: Financiering van zorginstellingen, Met speciale aandacht voor medisch-specialistische zorg, Deventer: Vakmedianet 2015, p. 119-126.

69 Kamerbrief d.d. 13 juli 2018, Winstuitkering door zorgaanbieders, p. 4; onder verwijzing naar de conclusies van EY: 'Onderzoek mogelijkheden tot bevorderen participatiemodel', p. 30-34 en p. 48-50.

70 Rapport Taskforce, De juiste zorg op de juiste plek. Wie durft?, p. 41. 
ratieve rechtsvorm biedt daarmee een flexibele structuur voor een netwerkorganisatie met een pluriform ledenbestand waardoor de maatschappelijke verankering en het draagvlak van het gezamenlijke ziekenhuis sterk wordt bevorderd.

\section{Governance gezamenlijke ziekenhuisorganisatie}

Verdere integratie van medisch specialisten door middel van individuele of collectieve participatie in de juridische en economische infrastructuur van het ziekenhuis bevordert niet alleen het alignement met de medische staf, maar bewerkstelligt evenzeer een meer evenwichtige inrichting van de governance met een eenduidige verantwoordelijkheidsverdeling. Als zorgaanbieder is de integrale ziekenhuisorganisatie normadressaat van de Wkkgz alsook primair aanspreekpunt voor de centrale aansprakelijkheid uit hoofde van de geneeskundige behandelingsovereenkomsten. De interne allocatie van deze verantwoordelijkheid en eventuele aansprakelijkheid wordt vervolgens via de wettelijke bepalingen van Boek 2 BW, de governanceprincipes en aanbevelingen van de GCZ 2017, alsmede de statutaire en reglementaire voorzieningen op een evenwichtige en doelmatige wijze gereguleerd. De raad van bestuur heeft in dat verband wettelijk, krachtens de jurisprudentie en op grond van de governanceprincipes en aanbevelingen van de GCZ 2017 met betrekking tot de rolvastheid, rolzuiverheid en rolbewustheid van de interne organen, een autonome positie met zelfstandige bevoegdheden om zijn verantwoordelijkheden ook daadwerkelijk te kunnen effectueren. ${ }^{71}$ Zulks onder integraal toezicht van een onafhankelijke raad van commissarissen die rechtstreeks toezicht kan houden op het bestuur en de gang van zaken, waaronder het primaire proces van de patiëntenzorg en daartoe eveneens een autonome positie en daarmee corresponderende bevoegdheden heeft. Als representatief orgaan dat in een juridisch en economisch participatiemodel de belangen van de deelnemende medisch specialisten behartigt, beslist de algemene leden- of aandeelhoudersvergadering over belangrijke onderwerpen als benoeming van bestuurders en commissarissen, fusies, splitsingen en overige organisatiewijzigingen alsmede de vaststelling van de jaarrekening met de daaraan verbonden winstbestemming. Het collectief van medisch specialisten en eventuele andere stakeholders zullen in dat verband wel de bevoegdheden en verantwoordelijkheden van zowel de raad van bestuur als de raad van commissarissen voor de gezamenlijke ziekenhuisorganisatie moeten respecteren. Bovendien zal een groot aantal ziekenhuizen, gezien de omvang van hun eigen vermogen, het aantal medewerkers en de daaraan verbonden ondernemingsraad, al snel onder de governancebepalingen van het bijzondere structuurregime van de nv/bv respectievelijk de coöperatie vallen of daar uit bestuurlijke en beleidsmatige overwegingen vrijwillig toepassing aan geven. ${ }^{72}$ Vanuit organisatorische optiek sluit deze wettelijke structuurregeling goed aan bij de Transparantieeisen van het Uitvoeringsbesluit WTZi en de actuele governancevoorschriften van de GCZ 2017. Het structuurregime voorziet in de inrichting van een governancestructuur met een onafhankelijke raad van commissarissen die op basis van autonome (controlerende en goedkeurings)bevoegdheden integraal toezicht houdt op de gezamenlijke ziekenhuisorganisatie en vergaande invloed heeft op de samenstelling van de raad van commissarissen en

71 Met name principe 4 (Inrichting governance) en hoofdstuk A (Algemene vergadering).

72 Art. 2:63a e.v. jo. art. 2:63e resp. art. 2:152/262 e.v. jo. art. 2:157/267 BW; waarbij de criteria voor de verplichte structuurregeling, kort samengevat, neerkomen op een eigen vermogen van ten minste $€ 16$ miljoen, ten minste honderd werknemers en de aanwezigheid van een voorgeschreven ondernemingsraad. 
- bij structuurvennootschappen - op de raad van bestuur. De coöperatieve rechtsvorm biedt in dit verband de mogelijkheid om de zeggenschapsrechten van de deelnemende medisch specialisten en de overige categorieën leden op een effectieve wijze te clusteren via een ledenraad. Door het principe van de ledendominantie zoals dat voortvloeit uit de nauwe betrokkenheid van de leden bij hun coöperatie, blijft de invloed van een dergelijke ledenraad op de samenstelling van de raad van bestuur van een structuurcoöperatie behouden.

\section{Slotbeschouwing}

In de afgelopen decennia zijn belangrijke stappen gezet in de ontwikkeling van de interne organisatie van het ziekenhuis, maar het blijft een complex proces met een gedifferentieerd belangenspectrum in een dynamisch krachtenveld. De medische professie en dan met name het vrije beroep vertoont in dat verband sinds jaar en dag een groot adaptief en absorberend vermogen: ondanks alle publieke en politieke sentimenten en verschillende stelselwijzigingen van overheidswege heeft het (fiscaal) zelfstandig ondernemerschap van de medisch specialist als autonoom handelend professional zich al die jaren kunnen handhaven. De MSB-vorming die daarvoor in het nieuwe systeem van integrale bekostiging blijkbaar nodig was, illustreert een paradoxale ontwikkeling in het voortschrijdend integratieproces van medisch specialisten in de ziekenhuisorganisatie. Zorginhoudelijk en ten aanzien van de bekostigingssystematiek vindt in toenemende mate een intensivering van de onderlinge samenwerking en integratie plaats, terwijl de focus van veel collectieven van medisch specialisten op fiscaal, financieel-economisch en organisatorisch gebied vooral gericht is op verzelfstandiging binnen en buiten het ziekenhuis. Naast alle verworvenheden, resulteert dit nieuwe samenwerkingsmodel in meerdere governancedilemma's die in de huidige context nog onvoldoende zijn doordacht of zelfs ronduit problematisch zijn. Voor het clusteren van de meerledige overlegstructuur met de verschillende onderdelen van de medische staf (MSB, VMSD en VMS) zijn in de praktijk inmiddels meerdere formele en informele scenario's ontwikkeld. Daarentegen heeft de meervoudige besturing van de ziekenhuisorganisatie in de afgelopen jaren (mede) aanleiding gegeven tot enkele ernstige crisissituaties en moeizaam te beheersen conflicten die door de huidige governancestructuur onvoldoende worden ingekaderd. De interne organisatie van dergelijke ziekenhuizen met een of meerdere MSB's ondersteunt noch faciliteert kennelijk in voldoende mate het zelfreinigend en oplossend bestuurlijk vermogen. Experimenten met vormen van cobestuur resulteren doorgaans in lastige belonings- en governancevraagstukken ten aanzien de wettelijke normering van inkomens in het semipublieke domein, het voorkomen van (de schijn van) belangenverstrengeling en een evenwichtige verdeling van bestuurlijke verantwoordelijkheden. Voor effectief intern toezicht wordt ten slotte de hoop gevestigd op informele en indirecte vormen van informatievoorziening en feitelijke interventiemechanismen.

Voor een meer evenwichtige en toekomstbestendige governancestructuur is dan ook een verdergaande integratie met een breder alignement tussen medisch specialisten en ziekenhuis geïndiceerd. Daardoor krijgt de interne ziekenhuisorganisatie meer aansluiting bij de toenemende zorginhoudelijke integratie en externe integrale bekostigingssystematiek in 
plaats van een verdergaande verzelfstandiging van (de vrijgevestigde) medisch specialisten waarmee in wezen wordt gepreludeerd op een revival van het veel bekritiseerde fenomeen van de regiomaatschappen. In een overgangsfase naar een dergelijke integratie kan alvast ervaring worden opgedaan met hybride financierings- en participatiemodellen of (andere) vormen van werknemersparticipatie, zoals een dienstverband met prestatiebeloning of werknemersaandelen. Medisch specialisten die daadwerkelijk inhoud willen geven aan hun ondernemerschap zullen zich uiteindelijk veel meer positioneren in de juridische en economische eigendomsstructuur van het ziekenhuis. Daarmee wordt de complexiteit van de interne ziekenhuisorganisatie sterk gereduceerd en een evenwichtige governancestructuur bevorderd die recht doet aan de feitelijke machtsverhoudingen binnen het ziekenhuis en de medisch specialisten niet alleen bevestigt in hun centrale rol, maar ook aanspreekt op hun integrale verantwoordelijkheid voor het totale zorginhoudelijke proces en een verantwoorde exploitatie en ontwikkeling van 'hun' ziekenhuis. De 'Echternach-processie' nadert dan met de voltooiing van het integratieproces zijn eindbestemming. 